\title{
PAINS AND PLEASURES OF INTERPRETING AND APPROPRIATING OBSCURITY: THE VERSUS MALIGNI ANGELI IN THE TWELFTH TO FIFTEENTH CENTURIES*
}

\author{
LUCIE DOLEŽALOVÁ
}

\begin{abstract}
The study addresses the subject of methods and character of medieval text transmission and interpretation through a case study of a brief obscure poem sometimes entitled Versus maligni angeli. While its origin is not known, it provoked four different detailed interpretations. All the commentators explain its meaning as Christian one but radically differ in the specific interpretations. They also justify the supposed devil's authorship of the poem in very different ways. They apply traditional strategies of Biblical exegesis to this idiosyncratic source. Although it is a mere opuscule, this case shows medieval exegetical flexibility as well as curiosity inherent in perceiving the created world. List of surviving manuscript copies of the verses as well as editions of two of the glossed versions are provided in appendices.
\end{abstract}

Keywords: medieval manuscript culture; medieval obscurity; medieval Latin; textual transmission; medieval interpretation; medieval literature

Sed multis et multiplicibus obscuritatibus et ambiguitatibus decipiuntur, qui temere legunt, aliud pro alio sentientes, quibusdam autem locis, quid uel falso suspicentur, non inueniunt: ita obscure dicta quaedam densissimam caliginem obducunt. Quod totum prouisum esse diuinitus non dubito ad edomandam labore superbiam et intellectum a fastidio reuocandum, cui facile inuestigata plerumque uilescunt.

"But hasty and careless readers are led astray by many and manifold obscurities and ambiguities, substituting one meaning for another; and in some places they cannot hit upon even a fair interpretation. Some of the expressions are so obscure as to shroud the meaning in the thickest darkness. And I do not doubt that all this was divinely arranged for the purpose of subduing pride by toil, and of preventing a feeling of satiety in the intellect, which generally holds in small esteem what is discovered without difficulty."

Aug. Doctr. christ. II, 6

Research leading to this study was supported by the European Regional Development Fund project KREAS, reg. no.: CZ.02.1.01/0.0/0.0/16_019/0000734, as well as by the Charles University Project Progres Q07, "Centre for the Study of the Middle Ages". I am much grateful to Peter Stotz, Carmen Cardelle de Hartmann, Ivan Prchlík and the anonymous reviewers of AUCP for their very kind help. 


\section{Obscurity of the Scripture and practice of interpretation and appropriation}

From all the possible obscurities, ${ }^{1}$ it is the obscurity of the Scriptures that is discussed most frequently throughout the Middle Ages. The Scriptures, as well as the entire world, are perceived as the reflection of God's will and nature and can never be completely grasped in this life - St. Paul describes the earthly grasp as per speculum in enigmate $\left(1\right.$ Cor 13, 12). ${ }^{2}$ In the passage quoted above, Augustine, within his most influential "theory of signs," presents his notion of scriptural enigma as challenge. ${ }^{3}$ He states that the same messages could have been put much more simply and clearly, and indeed, are revealed at other places in the Scripture in a straightforward way, but there is a greater pleasure coming from contemplating an enigma. The toil of decoding causes us to be more modest, and it gives us greater appreciation for what we learn. Due to Augustine, throughout the Middle Ages the Scripture was viewed as an intentionally encoded message that cannot be fully decoded in this life. Engaging with it, however, was a praiseworthy act bringing one closer to God. ${ }^{4}$

During the Middle Ages, there was actually no radical difference between elucidating the Bible - a sacred text into which God himself encoded the greatest mysteries - and explaining a text with a historical, identifiable author: ${ }^{5}$ in practice they were often very close to each other in their methods. ${ }^{6}$ The existence of a commentary to a text is, in the first place, an indication of the text's authoritative status - a text commented on is a text that is considered to deserve one's detailed attention. ${ }^{7}$ But to what degree does the existence of an interpretation, explanation, or commentary to a text imply that the text itself is obscure? Perhaps it rather implies that there was something unclear in the text (or in the relationship between the text and its relevance to perceived reality, or to established practice), but also that it ceases to be obscure for its reader who was able to decode it and is now offering a solution. Through the commentary, the degree of the text's obscurity diminishes, the text moves from obscurity to clarity. Unless the author believes that he or she is able to reduce the obscurity of a text, he is not likely to comment on it. Thus, the existence of a commentary suggests that the text commented on was perceived as

1 I use "obscure" here simply in the meaning of "unclear" although the concept is a complex one. For a possible definition, see, e.g., Brandt, Fröhlich, Seidel (2003). See also Doležalová, Rider, Zironi (2013).

2 Nunc videmus tanquam per speculum in aenigmate, tunc autem facie ad faciem. In the Douay-Rheims Bible: "We see now through a glass in a dark manner; but then face to face. Now I know in part; but then I shall know even as I am known." The King James version reads: "For now we see through a glass, darkly; but then face to face: now I know in part; but then shall I know even as also I am known." Within this volume, I cite the Vulgate always according to the Clementine version available at http:// vulsearch.sourceforge.net/html (last accessed May 5, 2020), and its English translation according to the Douay-Rheims Bible at http://www.drbo.org (last accessed May 5, 2020).

3 See, e.g., Markus (1957).

4 This is, of course, a very complex issue presented here in a simplified manner. For basic details, see de Lubac (1959-1964) and Smalley (1982).

5 The other crucial discourse on obscurity is found within poetics and rhetoric. The medieval advices to poets oscilate between suggestions of perspicuitas and a certain degree of obscuritas, see Ziolkowski (1996).

6 To my knowledge, there is no full comparative treatment of medieval exegetical methods, a large topic that exceeds the scope of this study.

7 Cf., e.g., Geerlings (2002: 1). 
an interpretable obscurity. The absence of a commentary, on the other hand, may imply either absolute clarity of the text (i.e. no need for a commentary), or, on the other hand, its absolute obscurity (i.e. failure to appropriate the text, no capability to write a commentary), or, finally, indifference towards the text (i.e. no interest in writing a commentary).

Any explanation is a sort of appropriation. It is within the context of appropriation that something is perceived as unclear and can consequently be made clear, and "one's own." Since the structures regulating the appropriation of texts are always socially and culturally bound, texts are interpreted again and again in new contexts, and the character of the appropriation tells often more about the rules of discourse in the appropriating culture than about the text itself. Commentaries provide an insight into the norms, the framework into which the original obscurity was made to fit, than about the obscurity itself. On the other hand, it might be possible to assess the efforts behind the appropriation: the more obscure the text, the more struggle lies behind its explanation, which might be articulated within the commentary. In cases where a number of commentaries exist from the same time, one can detect either the unanimity of exposition or a variety in it. The former indicates either a lesser degree of obscurity within the text, or a higher force of the norm, the latter suggests the opposite: that the text found itself at the edge, not belonging anywhere, not easy to appropriate.

Besides full scale commentaries, the actual character of interpretation and appropriation of a text can be discerned from interlinear glosses, changes to the text itself, as well as from analysis of the physical and cultural environment in which the text is transmitted. The present case study is an attempt at such a multi-faceted analysis of interpretation and appropriation of an obscure text.

\section{The Versus maligni angeli}

The text analysed here is a brief obscure poem of uncertain origin. It was first discovered and transcribed for the Benedictine edition of Du Cange's Glossarium by Lebeuf, ${ }^{8}$ and subsequently edited by Quicherat ${ }^{9}$ and Castets ${ }^{10}$ from individual manuscripts. Although mostly neglected by scholars so far, ${ }^{11}$ it was quite largely diffused and commented on and is found in a variety of environments in the twelfth to fifteenth centuries. An exploration of its reception thus serves as an apt case study of interpreting and appropriating obscurity in the Middle Ages.

The poem is usually transmitted without an author attribution and a title. The few titles that appear include Versus daemonis (Verses of a demon), Versus maligni angeli (Verses of a malign angel), Versus diaboli (Verses of a devil), Versus extranei (Verses from outside), and even Tractatus de fluvio Oronte (Treatise on the Orontes River). In the hith-

8 Du Cange (1840: 216).

9 Quicherat (1879: 602-603), edited from the Charleville-Mézières ms.

10 Castets (1887: 112-119), edited from the Montpellier ms.

11 There is one detailed article on the verses and their reception, Hilka (1937). In addition, there is a brief discussion of the verses in Schmidt (2008). I have briefly discussed it within Doležalová (2017). Specific aspects were addressed in studies discussed below. 
erto oldest known manuscript, Bourges, BM, 105, written at the end of the eleventh or the beginning of the twelfth century in Chezal-Benoît (Fig. 1), the poem reads:

[O]ppositum montem transcendere cernis orontem

Arma tua dextra capies et fer capud extra

Hinc gladio multos umbris mactabis inultos

Sed prius hoc unus puerorum fret [!] tibi munus

Lanx quę cum carne tibi dudum servit agarne

Iam prolatura tibi constat munera plura

Hinc et gallina dat vocem pandite lina.

Panibus indutos piscesque videte minutos

Trax capud orontis iacet hoc in corpore montis

Quem circumstabant acies et vociferabant

Amaratunta tili codoxia noxia nili

Pensa tibi dippus eris hoc in limine lippus

Victus amore pio sic cantat maxima clio.

The very approximate translation I propose is: ${ }^{12}$

Facing the mountain, you note Orontes descending ${ }^{13}$

You will seize your weapons with your right hand and take the head out

Hence you will elevate to the shadows many un-revenged with [your] sword

But before [that] one of the boys brings you this gift

A plate with meat which he humbly ${ }^{14}$ serves just now

Already about to bring forth to you many gifts

Hence the hen also gives the voice, spread out the ropes

Behold the diminished ${ }^{15}$ fishes clad in bread

Thracian head of Orontes, it lies in the body of the mountain

Around which the troops stood and exclaimed

Amaratunta tili codoxia noxia nili ${ }^{16}$

Consider for yourself, you will be Oedipus blind in this light

Defeated by pious love, thus sings the greatest Clio. ${ }^{17}$

The original source, meaning, and purpose of the poem are far from clear. At first sight, this looks like nonsense. Something is occurring - perhaps a fight - but no real story can be discerned. Two of the words, amaratunta and codoxia, are hapax legome$n a-$ they appear only here and their meaning is obscure. ${ }^{18}$ There are clear allusions to the Gospels (the miracle of the bread and the fish, and the simile of stretching the ropes,

12 The translations here and below are mine.

13 Or: You see Orontes ascending against the mountain.

14 Based on the medieval commentaries claiming that agarne is an adverb derived from Agar, i.e. Haggar, the servant of Sara (Genesis 16), meaning "in a servant-like manner."

15 Probably "divided into small pieces."

16 Based on the medieval explanations of the text the translation of this line would be: "In the second coming of the Lord the vain glory of the heretics will become to them the plague of the Red Sea" (see the discussion below).

17 Clio or Kleio is the Muse of history.

18 Cf. Du Cange (1840: 216) - the entry does not appear in the original edition of the dictionary, only in the version revised by Benedictines of St. Maur. 


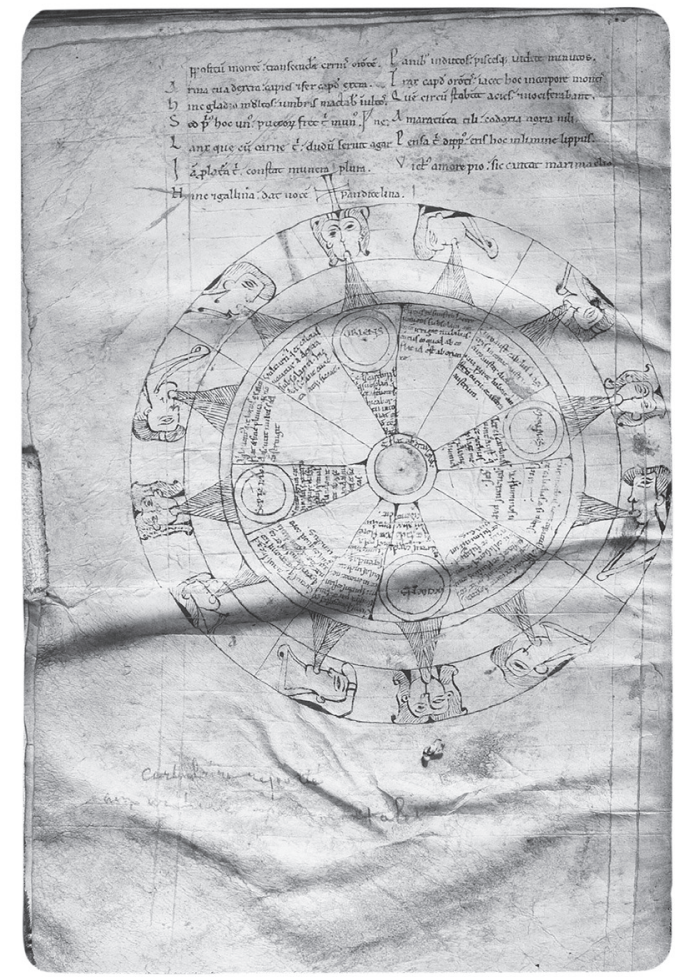

Fig. 1: Ms. Bourges, Bibliothèque municipale, 105, f. 95v.

i.e., the nets by the apostles), but also to classical culture (Oedipus and the Muse Clio). The use of the second person, which gives the poem a sense of appellation, is curious.

The readings of the poem differ from each other in the manuscripts and I am unfortunately not yet able to provide a critical edition of the text. Some of the variants are surely scribal mistakes, such as fret (line 4) standing for fert (sometimes substituted by fer or dat in the manuscripts), or the variants perlatura / parlatura / prolatura / prelatura (line 6 , clearly due to manuscript abbreviation), but even in such cases it is not always easy to decide which of the variants might have been the original one. In general, they point to the scribes' uncertainty concerning the overall meaning - uncertainty that remains till today. Noteworthy is the variant orantem (a praying one, acc. sg.) for orontem (Orontes River, acc. sg.) in line 1, which suggests that it is a person, not a river that ascends the mountain. Line 10 contains a variation between past and future tenses (circumstabant / circumstabunt, vociferabant / vociferabunt), thus calling into question whether the whole poem describes a past event or refers to the future. Many of the variants affect the meaning, ${ }^{19}$ but in each case the poem remains obscure.

19 Among others, there are, for example, lanx / laus (1. 4), trax / trux (1. 9), corpore / vertice / culmine / capite (1. 9), codoxia / quod doxia / codaxia / cenodexia (1. 11), noxia / naria (1.11), pensa / plexa (1. 12), and lumine / limine / munere / carmine / corpora (1. 12) (these are simply examples of the variety; 


\section{Exorcism?}

The most striking part of the poem is the totally incomprehensible line 11: Amaratunta tili codoxia noxia nili. A similar line is found in a manuscript in the Uppsala University Library ${ }^{20}$ and several further versions exist ${ }^{21}$ with scribbles on the beginnings or end of codices, or on the margins, that prevent us from interpreting their meaning. Searching for parallels offering some interpretable context, we find Carmina burana 55:

\section{Amara tanta tyri pastos sycalos sycaliri \\ Ellivoli scarras polili posylique lyvarras ${ }^{22}$}

In contemporary scholarly interpretations, the poem is considered a mixture of Greek, Latin, and nonsense, ${ }^{23}$ pretended Latin, or untranslatable gobbledygook. ${ }^{24}$ Aldous Huxley refers to it as a magic spell from the twelfth century when speaking of magic always being poetry. ${ }^{25}$ The poem follows Carmina Burana 54, which is an enumeration of various demons ending with an explicit exorcism. ${ }^{26}$ It is actually far from clear that the two poems are two separate texts: Carmina Burana 55 begins on a new folio but without the markedly larger initial characteristic of new beginnings in the codex. Thus it seems most likely that Carmina Burana 55 is the actual exorcist formula belonging to Carmina Burana 54. Indeed, very similar lines appear in a thirteenth-century exorcism. Roberta Astori reprints them with her "translation" suggestion:
Amara tanta tyri pastos sycalos sycaliri
celklivoli scarra polici posylisque lyvarras
"Un'abbondante dose di pozione amara di serpente impastare con salvia ben pestata / una quantita' opportuna de caprifoglio e una misura di urina e policaria." ${ }^{27}$

Another medieval exorcist poem includes a line close to line 9 of the Versus maligni angeli:

references to the particular manuscript witnesses preserving each variants will be included in an edition of the text which is under preparation).

20 It reads: Amara tonta tyri post hos sycalos sykaliri; Uppsala, UB, C 377, is a 14th c. sermon collection and the verse is here included on $\mathrm{f}$. $2 \mathrm{r}$ between two sermons, followed by five more verses, of which only one is reminiscent of our poem (see Appendix I). Similar lines are also found in Uppsala, UB, C 228, also a collection of sermons, but dating back to 1300, perhaps Paris University, and the lines are contained on the very last folio, $302 \mathrm{v}$ (see Appendix I).

21 Hilka (1934-1937: 2) mentions two, München, BSB, clm. 2611, f. 123r from Alderspach and Oxford, BL, Digby 53. Similar verses are found in Merseburg, DSB, 40, f. 188v, in Wien, ÖNB, Pal. lat. 303, f. $64 \mathrm{r}$ (for all the versions, see Appendix I).

22 München, BSB, clm. 4660, f. 18v, ed. Hilka, Schumann (1930: 110).

23 Beatie (1967: 18).

24 Parlett (1986: 31).

25 Huxley (1932: 227).

26 Inc.: Omne genus demoniorum, expl.: vos exorcizo, Larve, Fauni, Manes, / Nymphe, Sirene, Hamadryades, / Satyri, Incubi, Penates. / ut cito abeatis, / chaos in colatis, / ne vas corrumpatis / christianitatis (“... I exorcise you, Ghosts and Fauns, / Goblins, Sirens, Nymphs, and Dryads, / Satyrs, Nightmares, Household Gods, / Swift to Chaos get you gone, / And no more trouble Christendom. / And do Thou, O God, vouchsafe to keep us from our foes").

27 Astori (2000: 99). 
Si vis scire utrum homo sit obsessus an non, scribe ista verba in una carta vel littera: AGLA * $L A Y{ }^{*} E L E Y T H{ }^{*}$ et illos quatuor versus que vocantur versus dyaboli quia per se fecit illos versus:

Omimara chentazirim post hossita lossita lux

Ebulus lepolpes mala raphamius allilous

Helmo starius sed poli polisque

Lux capit horrontis latet vertice montis.

Dissen prieff sol man in sein hand legen. Recipit autem in manu, tunc non est obsessus, si autem non, tunc est obsessus. ${ }^{28}$

Here, the verses are called verses of a devil (versus diaboli) because he composed them himself (quia per se fecit illos versus).

Already Hilka noted the exorcist link: in a Wolfsthurn manuscript from the fifteenth century there are four lines that are, just like those quoted above, believed to force the demon to identify himself when the priest whispers them into the ear of the possessed person; the first two lines are similar to Carmina Burana 55, the second two lines are not in the Versus but (as Hilka points out) resemble another exorcism. Hilka suggests that the Wolfsthurn probably represents a version older than our Versus. Although all the other comparable examples are only from the fifteenth and sixteenth centuries, ${ }^{29}$ there are reasons to assume that the formula is much older, perhaps the ninth or tenth century. ${ }^{30}$ My conjecture is that our poem developed around the magic exorcist formula, and meaning was gradually added to it. This feature is thus most likely to be responsible for the poem's title Verses of a malign angel or Verses of a demon - these verses were either written by a demon, or can be used against him.

Although this suggestion cannot be proven now, its implications are thought-provoking: if the original basis of our poem was exorcism, that is magic or an incantation, then it was designed as obscure and enigmatic and was not expected to be interpreted at all. Magical incantations are meant to sound unusual and have an aesthetic dimension (they contain alliterations, rhymes, etc.) but they should be indiscernible as far as their meaning is concerned. Of course, some of the words generally remind the listeners of God and demons, or of other familiar concepts, but in the context of exorcism one is not expected to analyze the meaning and author's intentions. ${ }^{31}$

28 München, BSB, clm. 23325, f. 32v; and an inscription close to it in Vatican, BAV, Pal. lat. 794, f. 83v, cf. Caciola (2003: 245, n. 58). The author notes that the manuscript contains also a piece of paper with the same inscription. A paper with an inscription to be placed on the head of the possessed is evoked in München, BSB clm. 1352, f. 51.

29 Audin (1854: 296): “There are worthy Lutherans in Saxony who still repeat the singular exorcism, the invention of which is assigned to the Catholics by Jodocus Hocker in his Theatrum Diabolorum, on the authority of the doctor: Amasatonte, Tiros, Posthos, Cicalos, Cicaltri, Aeliapoli, Starras, Polen, Solemque, Livarrasque, Adipos adulpes, Draphanus, Ulphanus, Trax, caput Orontis. Jacet hoc in virtute montis." Cf. Hocker (1569: 76). Raabe (1969: 162) cites words linked to Simon Magus that are to be written on a piece of paper: Amarathonta, tiros, posthos, cicalos, cicattri, eliapoli, starras, polen, solemque, linarras, edipos, edulpes, mala, draphanus, ulphanus, trax caput orontis jacet hoc in virtute montis.

30 This statement is repeatedly made in the context of magic but there are no actual sources known to support it.

31 Formulas in which every word is meaningful of course also exist. The relationship between the two modes (or styles?) has not been, to my knowledge, fully explored yet. 
It is not evident in what exact way the exorcist formula could have been transformed into a poem commented on independently by at least four twelfth-century exegetes. It seems that there must have been a shift in its contextualization, which either happened by a chance (the verses were found by themselves and re-contextualized differently), or was somehow intended. Yet (as shall be discussed in detail below), the question of how an obscure text of suspicious origin got sufficient authority to receive serious attention might be anachronistic. Within medieval rich tradition of encountering obscurity as a natural part of the created world, this particular obscurity of an "external" origin (i.e. not created by a human but by a demon or a devil) might have been a natural challenge to the exegete and an obvious choice for elucidation.

\section{Manuscript transmission}

Thus far I have traced 37 manuscripts of the poem, two more described in medieval catalogues, and a medieval reference to another apparently lost copy. ${ }^{32}$ Seventeen of the manuscripts (and one lost copy) come from the twelfth century. Great majority of them originated in a monastic environment. Frequently the poem is accompanied by explanatory interlinear glosses, and, in addition, there are four independent commentaries to it, each witnessed in at least one twelfth-century manuscript, and each presenting a different interpretation of the enigmas of the poem. Three of them were known to Alfons Hilka who edited them in $1937,{ }^{33}$ the fourth one has passed unnoticed so far.

It should be stressed that the present analysis is only preliminary: there is no doubt that more manuscripts wait to be discovered. Several of the surviving copies are fragments without a title, or they contain the whole poems but integrated within other texts without any sign of distinction, and thus they are often not noted even in modern catalogues. The fact that there is no author or a fixed title presents further complications with the manuscript search. Yet, there are some transmission patterns.

To date I have traced five unglossed manuscripts of the poem. ${ }^{34}$ It is surely especially among the unglossed copies that many remain to be noticed. It is difficult to judge the status of the poem or an approach to it on the basis of these copies as the verses were usually only added at the beginning or at the end of the codex by a different (often later) hand. ${ }^{35}$ There is also for example the manuscript New York, PML, M 764 from Amor-

32 In the Appendix I and in the tables below, there are 46 manuscripts discussed, since also eight partial copies and specific versions, as well as one copy described in medieval catalogue (the Pontigny copy) are included.

33 See Hilka (1934-1937: 1-30). However, since Hilka was not aware of many manuscripts and did not include almost any context information, the commentaries should be re-edited.

34 They are:

Bourges, BM, 105, f. 95v,

Paris, BnF, lat. 2877 A, f. 27v,

Wien, ÖNB, Pal. lat. 2521, ff. 33v-34r,

Edinburgh, NL, 18.6.12, ff. 34v-35r,

Glasgow, UL, 205.

35 That is the case of the oldest known surviving copy, Bourges, BM, 105, where the verses appear on the last folio of a codex containing only Gregory the Great's Homilies to Ezekiel. The poem is accompanied by a sketch of the winds (fig. 1 ) that was made before the poem was copied (note how the text of the poem breaks to avoid the cross of the sketch) and seems unrelated to it. Paris, BnF, lat. 2877A is a small 


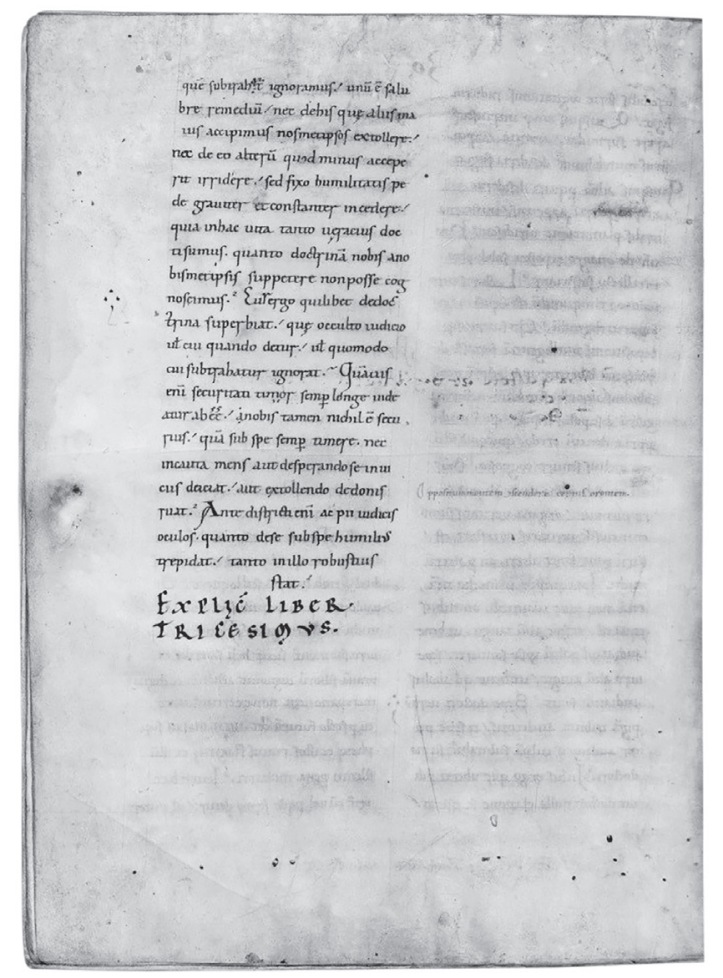

Fig. 2: Ms. New York, Pierpont Morgan Library, M 765, f. 148v (detail).

bach, where only the first verse of the poem appears, added at the end of an otherwise unified codex with Gregory the Great's (540-604) Moralia in Iob (Fig. 2). ${ }^{36}$ Alternately, the verses are integrated among other verses without being separated from them by a title, a void line or other means. In two manuscripts, ${ }^{37}$ they appear in the vicinity of poems by Marbode of Rennes (1035-1123).

Thus far I am aware of six glossed manuscripts. ${ }^{38}$ In most cases the glosses are interlinear but they vary in length. Three of the manuscripts ${ }^{39}$ are closely related to one

fascicle of 27 folios, which also contains one primary text, Honorius Augustodunensis' Elucidarium, with the brief addition De tribus Mariis, followed by our verses. In Glasgow, UL, 205, the verses are a sixteenth-century addition to a thirteenth-century codex with the collected works of Seneca.

36 For a description, see Hoffmann (2004: 14-15) who treats 27 codices coming from Amorbach in the 10th-11th c. (including New York, PML, M 765, which originated at the same time and place and also contains Moralia in Iob).

37 Wien, ÖNB, Pal. lat. 2521 and Edinburgh, NL, 18.6.12.

38 They are:

Besançon, BM, 862, f. 24,

Karlsruhe, BLB, St. Peter Perg. 12, f. 120v, from St. Peter im Schwarzwald,

Laon, BM, 23, f. 114v,

Paris, BnF, lat. 1628, f. 145r, from St. Amand-en-Pévèle,

Paris, BnF, nouv. acq. lat. 1543, f. 125v, from Hautmont,

Wien, ÖNB, s. n. 12702, f. 80r.

39 The two Paris manuscripts and the Besançon one. 


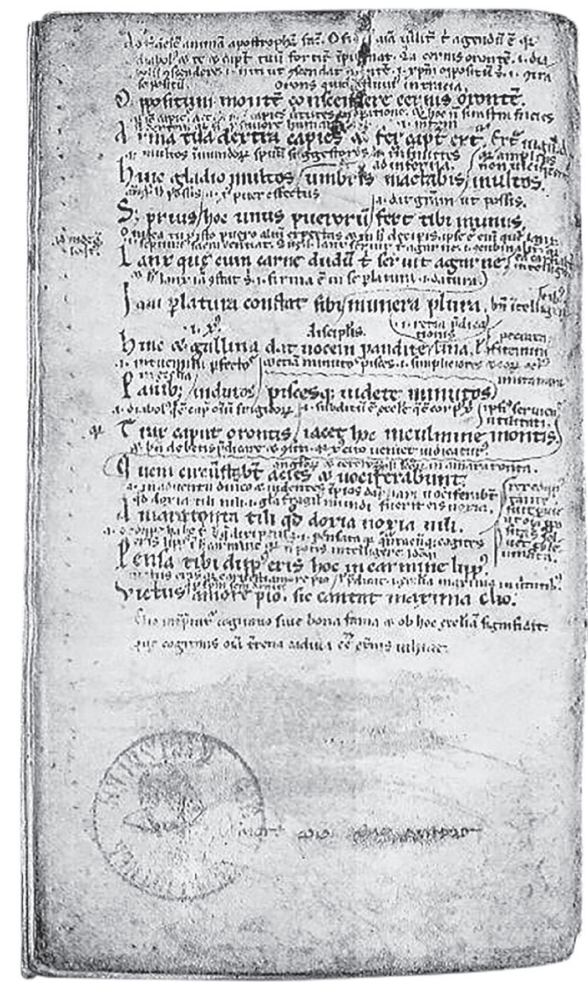

Fig. 3: Ms. Karlsruhe, Badische Landesbibliothek, St. Peter Perg. 12, f. 120v; Versus maligni angeli with interlinear glosses.

another. The Laon glosses are very brief and might be linked to the novelistic commentary, while the interlinear glosses in the Karlsruhe manuscript are different (Fig. 3); they are substantially longer and seem to be derived from the "exegetical" commentary. The most unusual is Wien, ÖNB, Pal. lat. 12702 discussed further, which places the poem among Virgil's poetry and refers to classical writers in its elucidation.

Hilka called the three different commentaries he edited "moral", "apologetic", and "novelistic" (moralisch, apologetisch, novellistisch). The newly found commentary (Charleville-Mézières, BM, 117, ff. 1v-19r) is the longest of all and includes a detailed description of the method of explanation applied, which is in line with Biblical exegesis. Thus I call it the "exegetical" commentary. While the commentaries seem to have originated independently, the "exegetical" and "novelistic" share several common features and biblical references.

The "moral" commentary does not include a general introduction, it consists only of comments on the individual lines, and thus it resembles a set of longer glosses. The poem does not appear in it independently, it is only included within the commentary. It survives in five manuscripts, two of which were known to Hilka. ${ }^{40}$ The previously

40 They are:

München, BSB, clm. 2561, f. 161v, 


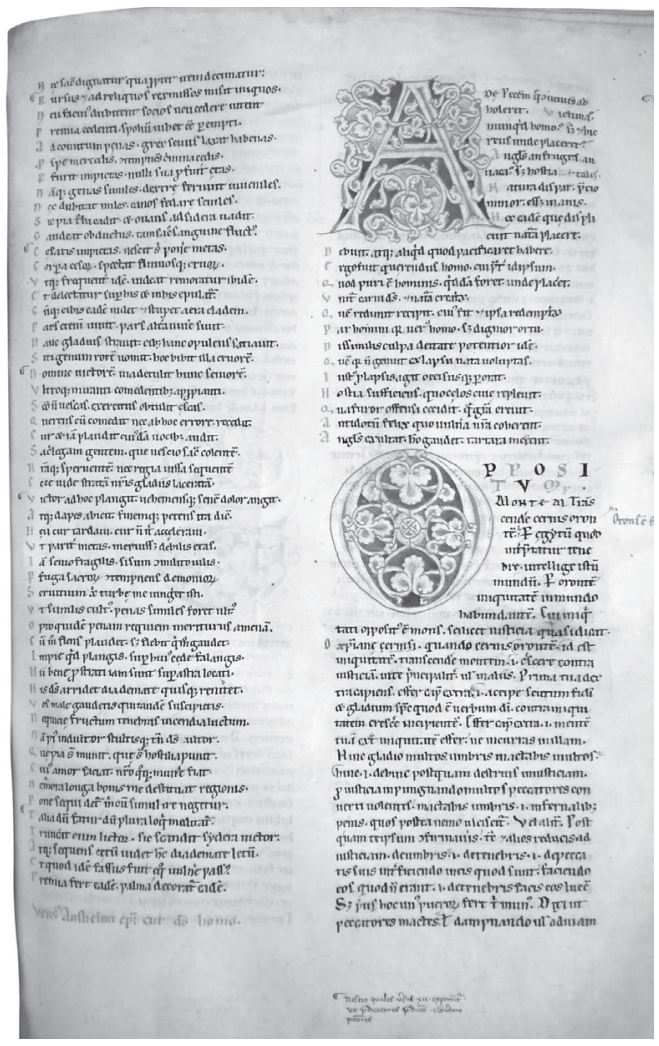

Fig. 4: Ms. Heiligenkreuz, Stiftsbibliothek, 11, f. 150r; the Versus within the "moral" commentary with a note in the lower margin: Nescio quales versus XII exponuntur ut predicatores predicent et convertant peccatores.

unnoticed manuscript, München, BSB, clm. 18921, from Tegernsee, contains a shortened version of this commentary but includes a note that the full version can be found in a passionale: Nota quod istos versus et exposicionem plenius invenies in passionali parte estivali post legendam de translatione beate Marie Magdalene. ${ }^{41}$ The manuscript München, BSB, clm. 2561, does indeed feature the verses after the Life of Mary Magdalene, but it is a miscellany, not a passionale, and the codex seems to have been written and always kept in Aldersbach. Thus the reference is probably to another, lost, copy. The Heiligenkreuz manuscript includes a later marginal note in lower margin of the folio with the poem: Nescio quales versus XII exponuntur ut predicatores predicent et convertant peccatores ("I do

Freiburg, UB, 9, f. 53v,

Zwettl, SB, 13, f. 207v, newly noted,

Heiligenkreuz, SB, 11, ff. 150r-150v, newly noted,

München, BSB, clm. 18921, newly noted, much condensed version.

The Heiligenkreuz and Zwettl manuscripts are clearly connected, each of them containing legends for liturgical use, but also a number of shorter varied texts. In both the poem is followed by De nequitia heretici and two more stories from Gregory of Tours' Miracles.

41 F. 22v. 
not know what twelve verses are explained so that preachers would preach and convert sinners"; fig. 4). ${ }^{42}$ This certainly, besides providing a summary of the poem's meaning, indicates a medieval reader's bafflement at its obscurity.

The "apologetic" commentary ${ }^{43}$ survives in eleven manuscripts (Hilka knew five of them). ${ }^{44}$ In addition, there are two medieval catalogue entries referring to further copies. ${ }^{45}$ Although this commentary is, like all the others, anonymous, among the five manuscripts unnoted by Hilka that I have traced, there are three manuscripts, ${ }^{46}$ two of them already from the twelfth century, in which the text appears together with exegetical works by Herveus Burgidolensis (Hervé de Bourgdieu, ca. 1075-1149 or 1150). ${ }^{47}$ Also the manuscript from Pontigny that is now lost included the verses and commentary together with Herveus' writings. ${ }^{48}$ The commentary to this poem is not listed among Herveus' writings in a circular written after his death characterizing him and listing his works, ${ }^{49}$ but it might have been easily omitted because it was brief. In any case, it seems to fit his interests: Herveus is the only known medieval commentator on a similarly enigmatic opuscule, the Cena Cypriani, which may be seen as parallel to our verses in many respects. ${ }^{50}$ In two manuscripts (Tours and Wooster) a commentary to our verses directly follows Herveus' commentary to the Cena Cypriani. Thus, although it remains to be proven, it seems plausible to suggest that Herveus might have authored the commentary.

In four later copies with a number of common variants ${ }^{51}$ the commentary is titled Expositio versuum extraneorum, attributed to Joachim de Fiore and transmitted among

42 F. 150r.

43 Ed. Hilka (1934-1937: 13-21), and also transcribed (with errors) from the Montpellier ms. by Castets (1887: 112-119).

44 They are:

Basel, UB, A. II. 25, ff. 43r-45v, noted by Stegmüller, $R B$ no. 4055, 2 (this is the only ms. he notes and refers to it as Ps. Joachim de Fiore, Expositio versuum extraneorum),

Bruxelles, BrB, 5387-96, ff. 115v-119v,

Bruxelles, BrB, 10038-53, ff. 49v-54v,

Innsbruck, UB, 355, ff. 82r-82v-the commentary to our verses included here is much shorter and only partial (pertains to verses 1-6); see Hilka (1934-1937: 21),

Ivrea, BC, VI (74), ff. 64r-68v, linked to Joachim de Fiore - I was not able to consult this manuscript yet; I assume the presence of the poem based on the title in the catalogue: Expositio versuum extraneorum; the contents of this manuscript are close to that of Madrid, BN, 9731,

Madrid, BN, 9731, ff. 182v-184v, linked to Joachim de Fiore,

Montpellier, BU, Méd. H.4, ff. 127r-128v - Castets' (1887) edition is based on this ms.,

Roma, BV, E5, ms. not noted before, from Fleury (Benoît-sur-Loire),

Tours, BM, 257, f. 150v, ms. not noted before,

Vatican, BAV, Ottob. lat., 1758, ff. 158v-159r - only a fragment of the commentary with several changes,

Wooster, Ohio (no call number), f. $117 \mathrm{v}$, ms. not previously noted.

45 Peñiscola Castle, no. 134 in the catalogue; this codex has similar contents as Madrid and it was suggested that they are identical, the presence of the Versus with the apologetic commentary is assumed only from the title: Expositio versuum extraneorum.

The other is a 12th c. ms. from Pontigny described in a catalogue from 1794.

46 Roma, Tours, and Wooster.

47 Cf. Oury (1971) and also Clément (1869: 344-349).

48 See Vernet (1981: 667), who also notes several additional manuscripts compared to Hilka.

49 Edited in PL 181, 9-12. It is usually called Epistola vitam et libros magistri Hervei continens in the mss.

50 For details see Doležalová (2007: 54-58).

51 Ivrea, Madrid, Peñiscola and Basel. 
his other works. ${ }^{52}$ Both Madrid and Ivrea also contain Pseudo-Methodius Patarensis' De principio et fine seculi. Although Joachim's authorship has always been questioned and is indeed impossible, the link to prophecies is important. Finally, we find this commentary together with Late Antique material ${ }^{53}$ and within miscellanies. ${ }^{54}$ The possibility that the text was written already in Late Antiquity exists but cannot be verified.

One of the copies included in this group is a hitherto unnoticed fifteenth century fragment of a commentary based on the apologetic commentary. ${ }^{55}$ Yet, its opening paragraph is different (inc. Heretici licet ab exordio natentis [!] ecclesie molliti), and later it mentions Czech heretics: Aliquociens vero contigit ut subdolus ille hereticorum lapsus magnam sibi partem huius populi subiugans inquinaret uti et nunc in regno Boemie et alibi inquinat. Unfortunately the text ends soon after, without having finished commenting on the second line of the poem. Other texts within the codex are primarily chronicles, and the fragment follows materials from the council of Constance 1414-1418. Thus, it is a curious example of appropriating the "apologetic" commentary in the fifteenth century, and associating the general heretics mentioned in it with particular contemporaty danger.

The "novelistic" commentary seems to survive in nine manuscripts all originating from Central Europe. ${ }^{56}$ Hilka's edition presents two recensions (a shorter and a longer one), but the oldest surviving manuscript, which was so far unnoticed (Zwettl, SB, 355, Fig. 5), is different from them, while revealing similarities to both, and thus the edition should be reconsidered. In some of the manuscripts, there is a prologue addressed to a certain pater Hugo wherein the supposed origin of the poem is described. This commentary is most frequently transmitted in a literary context among poems and fictional texts but we find also prayers and other brief devotional texts in its vicinity. Perhaps the most curious manuscript of all, worthy alone of a particular case study, is Praha, Kap, A 79/4, where the commentary is followed by another obscure poem very similar in style also accompanied by a commentary. ${ }^{57}$

One manuscript ${ }^{58}$ contains a commentary to the verses (inc. Mediator dei et hominum homo Christus Ihesus leviatan quem) that has passed unnoticed so far and seems to survive in this sole manuscript. The text which I call the "exegetical" commentary, covers 19 folios of the manuscript and includes a lot of extra material, such as a discussion of the meanings of the names of the apostles, or of virtues and vices. ${ }^{59}$

52 I have analyzed this group of manuscripts in more detail in Doležalová (2016: 201-213).

53 In Bruxelles, BrB, 10038-53 and Montpellier, BU, H.4.

54 In Bruxelles, BrB, 5387-96 and Innsbruck, UB, 355.

55 In Vatican, BAV, Ottob. lat. 1758.

56 They are:

Darmstadt, HB, 947, ff. 105r-107r, not noted before,

Kraków, BJ, 126, ff. 45r-45v, indicated to me by François Dolbeau,

München, BSB, clm. 23390, f. 56r, Hilka - only a fragment of the commentary, and much shortened,

Praha, Kap, A 79/4, ff. 286r-287r, Hilka - a shorter version,

Praha, Kap, B 62, ff. 136v-137r, Hilka - a shorter version,

Salzburg, SB, St. Peter, a.VII.17, ff. 85r-85v, Hilka - a longer version,

Wien, ONB, Pal. lat., 1062, ff. 89v-90r, Hilka - a shorter version,

Wrocław, Ossolineum, 601, ff. 325r-326v, not noted before,

Zwettl, SB, 355, ff. 105v-107v - between the versions, mostly closer to the longer one.

57 Also transcribed by Hilka (1934-1937: 30).

58 Charleville-Mézières, BM, 117.

59 I am currently preparing an edition of the text. 


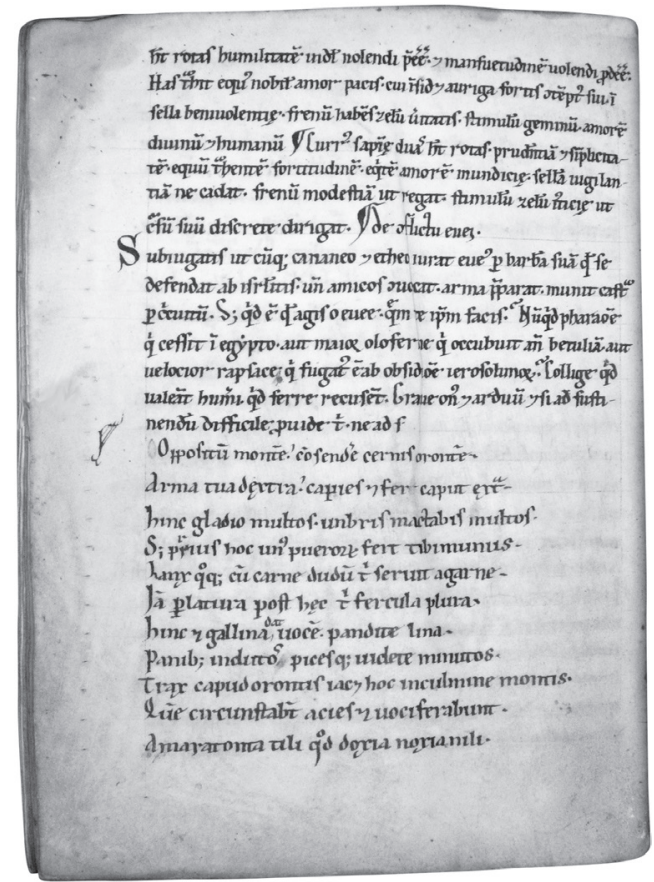

Fig. 5: Ms. Zwettl, Stiftsbibliothek, 355, f. 105v; Versus maligni angeli with the "novelistic" commentary.

\section{Times and places}

As it was already noted, each of the versions survives in at least one twelfth century copy. Actually, it seems that it was in the twelfth century that the text was copied most frequently:

\begin{tabular}{|c|c|c|c|c|c|c|}
\hline century & XII & XII-XIII & XIII & XIV & XV & total \\
\hline apologetic 60 & 2 & 3 & 1 & 3 & 3 & 12 \\
\hline novelistic & 1 & 1 & 1 & 2 & 4 & 9 \\
\hline moral & 2 & & 2 & 1 & & 5 \\
\hline exegetical & 1 & & & & & 1 \\
\hline only verses & 3 & 1 & & & 1 & 5 \\
\hline glossed & 4 & 1 & & & 1 & 6 \\
\hline different verses & 3 & & 1 & 4 & & 8 \\
\hline total & 16 & 6 & 5 & 10 & 9 & 46 \\
\hline
\end{tabular}

${ }^{60}$ Here and further on, too, also the lost Pontigny copy signalled in the catalogue has been counted, and, although that is a conjecture, it is assumed that it included the apologetic commentary. 
The manuscripts come from various environments. The fact that no manuscript is known to have been associated with mendicant orders should not be overemphasized: itinerant preachers' books were more liable to destruction, and, at the same time, some of the codices of "unknown" origin might have well been copied by a Franciscan or a Dominican. Many of the fourteenth and fifteenth century "unknown" copies actually seem to have been in private possession.

\begin{tabular}{|c|c|c|c|c|c|c|}
\hline origin & XII & XII-XIII & XIII & XIV & XV & total \\
\hline Benedictine & 7 & 5 & & 1 & & 13 \\
\hline Cistercian & 5 & & 4 & & & 9 \\
\hline Carthusian & & & & 1 & 1 & 2 \\
\hline Augustinian & 1 & & & & 1 & 2 \\
\hline University & & & 1 & 1 & & 2 \\
\hline Cathedral & 1 & & & & & 1 \\
\hline Papal lib. & & & & 1 & & 1 \\
\hline unknown ${ }^{61}$ & 2 & 1 & & 6 & 7 & 16 \\
\hline total & 16 & 6 & 5 & 10 & 9 & 46 \\
\hline
\end{tabular}

It is not the case that a certain version would be associated with a particular environment: both Benedictine and Cistercian monasteries from which most of the manuscripts come each had several versions:

\begin{tabular}{|c|c|c|c|c|c|c|c|c|}
\hline origin text & apo & novel & moral & exeg & verse & gloss & diff & total \\
\hline Benedictine & 2 & 1 & 2 & & 3 & 3 & 2 & 13 \\
\hline Cistercian & 1 & 2 & 3 & 1 & & 1 & 1 & 9 \\
\hline Carthusian & 1 & 1 & & & & & & 2 \\
\hline Augustinian & & & & & & 1 & 1 & 2 \\
\hline university & & & & & & & 2 & 2 \\
\hline cathedral & 1 & & & & & & & 1 \\
\hline Papal lib. & 1 & & & & & & & 1 \\
\hline unknown & 6 & 5 & & & 2 & 1 & 2 & 16 \\
\hline total & 12 & 9 & 5 & 1 & 5 & 6 & 8 & 46 \\
\hline
\end{tabular}

61 When the provenance is not known, the codex was, especially during later Middle Ages, most likely in a private rather than monastic possession. These manuscripts are primarily those with literary contents (see the discussion below), and might have originated in a school environment. 
Also comparing the times and the areas, ${ }^{62}$ we get quite a complex picture:

\begin{tabular}{|c|c|c|c|c|c|c|c|}
\hline XII & 9 & 1 & 3 & 3 & & & area \\
\hline Bent. & $\begin{array}{c}\text { French }+ \\
\text { Belgian }\end{array}$ & British & $\begin{array}{c}\text { German }+ \\
\text { Swiss }\end{array}$ & Austrian & $\begin{array}{c}\text { Central } \\
\text { European }\end{array}$ & Italian & total \\
\hline XII-XIII & 3 & 1 & 1 & 1 & & & 6 \\
\hline XIII & 1 & & 3 & 1 & & & 5 \\
\hline XIV & 3 & & 3 & 2 & 1 & 1 & 10 \\
\hline XV & 1 & 1 & 1 & & 4 & 2 & 9 \\
\hline total & 17 & 3 & 11 & 7 & 5 & 3 & 46 \\
\hline
\end{tabular}

Most revealing for the patterns of transmission is a comparison of the types of texts and areas:

\begin{tabular}{|c|c|c|c|c|c|c|c|}
\hline text area & $\begin{array}{c}\text { French + } \\
\text { Belgian }\end{array}$ & British & $\begin{array}{c}\text { German }+ \\
\text { Swiss }\end{array}$ & Austrian & $\begin{array}{c}\text { Central } \\
\text { European }\end{array}$ & Italian & tota \\
\hline apologetic & 7 & & 1 & 1 & & 3 & 12 \\
\hline novelistic & & & 2 & 2 & 5 & & 9 \\
\hline moral & & & 3 & 2 & & & 5 \\
\hline exegetical & 1 & & & & & & 1 \\
\hline $\begin{array}{c}\text { only } \\
\text { verses }\end{array}$ & 2 & 2 & & 1 & & & 5 \\
\hline glossed & 5 & & 1 & & & & 6 \\
\hline $\begin{array}{c}\text { different } \\
\text { verses }\end{array}$ & 2 & 1 & 4 & 1 & & & 8 \\
\hline total & 17 & 3 & 11 & 7 & 4 & 3 & 46 \\
\hline
\end{tabular}

From this table it becomes clear that Britain did not know any of the commentaries; in Italy there was only the "apologetic" commentary (and only in 14th-15th c.); the "moral" commentary circulated only in German speaking area, and the "novelistic" only in German speaking area and further east (where it got only in the 14th-15th c.). Interestingly, the Cistercian monastery at Zwettl had both the "novelistic" commentary (a twelfth century copy) and the "moral" commentary (a thirteenth century copy, perhaps directly derived from that of Heiligenkreuz). Similarly, it seems that at the council of Basel, both the "apologetic" and the "novelistic" commentary circulated. ${ }^{64}$

62 There is a substantial simplification in this table: manuscripts of unknown provenance were placed in it to the areas where they are presently kept.

63 Bohemia, Poland, Hungary.

64 The former then owned by Carthusians of Basel, the latter included, with many other texts, in a miscellany now in Kraków. The late medieval Church councils in general played crucial role in text dissemination (Hobbins 2009: 193-197). 


\section{Obscure explanations of obscurity}

The commentaries each explain the poem in a specific way, but, as A. Vernet observed, they are not very lucid in themselves:

Le diable en effet est poète à ses heures [...] mais c'est un auteur difficile dont les vers obscurs défient la glose, tels ces versus maligni angeli (inc. Oppositum montem...) aussi énigmatiques que les commentaires destinés à les éclairer qui les accompagnent dans plusieurs manuscrits du XII ${ }^{e}$ siècle. ${ }^{65}$

Thus, a closer look at them will not necessarily make the poem itself any clearer, but will rather show the variety of approaches to obscurity.

As far as the process of appropriation is concerned, the commentaries are in accordance: in each case the explanation of the poem corresponds with Christian beliefs. Each of the commentators interprets the fight as the fight between good and evil with a moral for the reader. That the poem is aligned with the teachings of the Scriptures is expressed explicitly in the "exegetical" commentary: quorum [versuum] plane mysticus et per omnia doctrine ecclesiastice concordans sensus ("whose meaning is clearly mystical and in accordance with the church doctrine in all aspects"). ${ }^{66}$

Although the glosses merely explain the figurative meanings of individual words, the glossed manuscripts (with the notable exception of Wien, ÖNB, s. n. 12702) reveal the very same nature of the framework of the poem's explanation: namely Christian moral context. ${ }^{67}$ Similarly, the "moral" commentary is basically a longer gloss offering fuller elucidation of individual lines but no overall meaning. The other three commentaries, on the other hand, include also a general summary of the poem's contents. The "apologetic" commentary perceives the meaning of the poem thus:

...ęcclesia vel quilibet fidelium per eos docetur sive monetur habere cautelam adversus hereticos super catholicum populum insurgentes, et gladio verbi Dei percutere eos, atque diabolum, cuius ipsi membra sunt, ab eis amputare, ut ad Christum possint pervenire. Fallacem quoque persuasionem ipsius hostis que per eos fit, et mortiferam eorum doctrinam cavere monetur vocemque salvatoris subtili receptaculo mentis percipere et miraculum quinque panum ac duorum piscium, ubi reseratio Testamenti Veteris figurata est, intelligere. Dehinc per huius vocis intelligentiam panumque fractionem ostenditur eiusdem crudelis adversarii deiectio, dum ad Christum convertitur magna pars hereticorum, qui eiusdem hostis erant membra et undique defendebantur contra catholicos ab heresiarchis oblatrantibus. Sed et ipsorum heresiarcharum perditio demonstratur, que fiet in adventu iudicis, quin in abyssum eos arrogantia ipsorum demerget. Rursumque monetur quilibet nostrum ut lancem iuste ponderationis teneat et videb-

65 Vernet (1950: 384).

${ }^{66}$ Charleville-Mézières, BM, 117, f. 2r.

67 In the case of Karlsruhe, BLB, 12, the glosses are closely connected to the "exegetical" commentary, while the versions in Paris, BnF, n. a. lat. 1543, Paris, BnF, lat. 1628, and Besançon, BM, 862 are linked to each other but are not derived from any of the noted commentaries. Paris, BnF, 1628 might be directly dependent on Paris, BnF, n. a. lat. 1543-the third line, which has no gloss in Paris, BnF, n.a. lat. 1543, is omitted entirely here, while the rest is almost identical (to compare the two versions, see Appendix II). The glosses in Besançon, BM, 862 are much shorter but undoubtedly derive from the same model. 
it in sentenciis hereticorum tenebras, in quibus imperiti lumen esse putant, si pie religionis amor in eius corde regnaverit. ${ }^{6}$

"The Church or anyone among the faithful is taught or reminded through them (the verses) to be cautious with heretics rising up over the Catholic people, and to strike them with the sword of the word of God, and to cut away from them the devil, whose limbs they are, so that they can reach Christ. It is advised to beware the deceitful persuasion of the enemy which comes through them, and their fatal teaching, and [rather] to perceive the voice of the Savior by the subtle reservoir of the mind, and to comprehend the miracle of the five loaves of bread and two fishes, in which the unlocking of the Old Testament is formed. Hereafter, through the understanding of this voice and the division of the bread, the rejection of the same cruel adversary is shown, while a great part of the heretics, who were the limbs of the same enemy and were everywhere protected from Catholics barked at by heresiarchs, are converted to Christ. But the ruin of the heresiarchs shows what will happen on the day of Judgement. Indeed, their arrogance will plunge them into an abyss. And again each of us is advised to hold the plate weighing the just, and we will see darkness in the judgments of the heretics, where the inexperienced consider there to be light, darkness, if the love of pious reverence for God reigns in their heart."

The "novelistic" commentary states more simply:

Scripsit ei preterea antiquus hostis hec carmina in quibus suam deiectionem, Christi incarnationem, apostolorum predicationem, gentium conversionem, ultimum quoque tremendumque iudicium sub enigmate breviter comprehendit. ${ }^{69}$

"Thereafter the ancient enemy wrote to him these poems in which he briefly and in a riddle-like manner treated his [own] fall, the incarnation of Christ, the preaching of the apostles, the conversion of the gentiles, and the last and fearful judgment."

The "exegetical" commentary describes:

Loquitur enim de pugna, quam gerit adversus Christum et eius ecclesiam et de eorum victoria. de adimpletione Sacre Scripture in nativitate ac passione Christi, et de die iudicii, fatendo veritatem, fidelibus operans in fide confirmationem et infidelibus pro detractione fidei graviorem condemnationem. ${ }^{70}$

"In fact, it speaks of a fight that [the devil] fought against Christ and his Church, and of their victory, of the fulfillment of the Sacred Scripture in the nativity and passion of Christ, on the day of the judgment acknowledging the truth, bringing to the faithful ones confirmation of their faith, and to the unfaithful ones, for the removal of faith, a very severe condemnation."

Although in this respect, the commentaries resemble one another linking the poem to the Last Judgement and the final victory of Christ / Church over the devil / heretics, on the level of the explanation of individual words they are quite different. Among other, Hilka cites the example of Orons, the Orontes River, which is a cold river in Thracia and

68 Here as in Roma, BV, E 5, ff. 150v-151r.

69 Zwettl, SB, 355, f. 106r, and Hilka (1934-1937: 7, 2nd column); the first recension by Hilka (1934-1937:

7, 1st column) has: Fecit ei preterea nequam spiritus versiculos suprascriptos in quibus suam e celo precipitationem, Salvatoris incarnationem, apostolorum predicationem, gentium vocationem, Iudeorum cecitatem, ultimum quoque tremendumque iudicium sub enigmate breviter comprehendit.

70 Charleville-Mézières, BM, 117, f. 2r. 
the place of the devil in the "novelistic" (and also in the "exegetical") commentary; ${ }^{71}$ in the "apologetic" commentary it is a river in Babylon, the city of false and fallen heretics; in the "moral" commentary it is the river of Egypt, which signifies this world full of inequality. ${ }^{72}$

The commentators struggle to find meaning for the difficult words and phrases, and quite frequently provide more suggestions without preferring one. The presence of these problematic words is not explicitly addressed, but it can be assumed that they were connected to the poem's authorship and associated with the "obscure" language of the devil. Only the novelistic commentary allows another interpretation: it describes the schoolboy trying to compose poems "from the material given to him" by the master (de data sibi a doctore materia componere vellet carmina), which could mean that the teacher assigned the pupil specific words that had to be used within the poem.

While the "moral" commentary does not include anything beyond explications of the individual lines of the poem, the other commentaries add a general introduction in which they address the problem of authorship as well as the general meaning of the text. The newly found "exegetical" commentary also includes a lot of other material, such as a long treatment of virtues and vices taken from Gregory the Great's Moralia in Iob, or etymologies of the apostles' names who are compared to fish jumping high from the water. The "moral" commentary is close to interlinear glossing, the "apologetic" to an anti-heretic sermon, the "novelistic" to a story, and the "exegetical" commentary to biblical exegesis or catechetic teaching. Although each does so in a different way, each of the commentators is nevertheless completely certain that there is a meaning behind the text and they shape the text to fit the mold of Christian moral teaching.

\section{The devil's authorship}

None of the commentaries include any reflection on the choice of the text to comment on. ${ }^{73}$ There is no trace of the source of its authority, or a reason for writing about it. A possible explanation is exactly the authorship of the poem, which the three commentaries that include a kind of introduction (the "apologetic", "novelistic", and the "exegetical" one) all agree on: the poem was composed by the devil or a demon. This extraordinary authorship is manifest not only from some of the titles, ${ }^{74}$ but is also discussed within the commentaries themselves. Because all the commentators agree that the poem has

71 The coldness of Orontes is found by Isid. Orig. XIII, 21, 17: Fluvius Syriae qui vocatur Orontes iuxta Antiochiae muros decurrens, qui a solis ortu oriens non longe ab urbe mari conditur, quem de originis suae tractu Orontem veteres Latine appellavere. Cuius fluentis ex ipso impetu frigidioribus, et zephyris assidue ibi spirantibus tota civitas momentis prope omnibus refrigeratur. The explanation of why should the devil be cold reads in the "exegetical" commentary: Qui bene diabolum signat, qui non solum in se frigidus est ab omni bono, sed etiam eos in quorum mentibus regnat ardentes quidem libidine ceterisque viciis facit, sed a feruore caritatis ceterarumque virtutum frigidos reddit (Charleville-Mézières, BM, 117, ff. $3 \mathrm{v}-4 \mathrm{r})$.

72 Hilka (1934-1937: 25-29).

73 This subchapter, in a somewhat different form, is included also in Doležalová (2014: 321-330).

74 In addition to those already mentioned is the special copy Oxford, BL, Digby 53, entitled: Versus demonis Johanni heremite quibus occupatus solvendis cessaret ab oracione. Thus, the verses were supposedly given as a type of riddle to John the Hermit (ca. 1050-1143). 
a Christian moral meaning, they feel compelled to explain how it is possible that it was actually written by a demon or a devil. A certain hesitation or bafflement may be felt in their tones.

The author of the "apologetic" commentary says that it is not clear whether the poem was written by a devil or an angel. It could have been the devil because, as all power comes from God, the devil would not have been able to say something wrong. ${ }^{75}$ The author refers to the biblical Balaam whose words, through God's intervention, were turned into good:

Hos versus composuisse fertur malignus angelus, et tamen recta sunt, nisi fallor, que in eis dicuntur, quia nullus malignorum spirituum quidquid agere vel loqui potest, nisi quod disponente deo permittitur. Non est enim potestas nisi a Deo. Et videlicet voluntas quidem demonum semper sit iniusta, potestas tamen eorum semper est iusta, quia voluntatem a se ipsis habent, sed a Deo potestatem. Unde et scriptum est quod 'spiritus domini malus irruebat in Saul'. Domini enim erat ipse nequam spiritus per licentiam potestatis iuste, sed malus per maliciam voluntatis iniuste. Sic et iste, qui versus istos composuit, fortasse spiritus Domini malus fuit. Non ergo videatur incredibile, quia malignus spiritus aliquid loqui volens ad deceptionem fidelium, conpulsus sit ea loqui per que fideles contra deceptionem cauti redderentur, vel a deceptione liberarentur, quoniam Scriptura Sacra docente cognovimus quod et Balaam populo Israel maledicere voluit, sed disponente Dei sapientia benedixit ei. Aliis tamen visum est quod angelus sanctus hos versus composuerit, quod et nos ipsi approbamus, licet quedam ex libris gentilium in eis cernamus. Sed quicumque eorum auctor sit... ${ }^{76}$

"It is assumed that these verses were composed by a malign angel, but nevertheless the things told in them are true, if I am not mistaken, because none of the malign spirits is able to do or say anything unless permitted by the will of God. Indeed, there is no ability except that given by God. And although the will of demons is obviously always unjust, their ability is always just, because they possess the will from themselves, but the ability from God. Thence it is also written the evil spirit from God came upon Saul [1 Kings 18,10]. Indeed, this vile spirit was from the Lord through the freedom of just ability, but evil through the evilness of unjust will. Thus also the one who composed these verses was perhaps an evil spirit from the Lord. Therefore it should not seem incredible that the malign spirit wishing to say something to deceive the faithful should be forced to say things through which the faithful would again become cautious concerning the deception, or freed from the deception, because thanks to the teaching of the Sacred Scripture we know that also Balaam wanted to curse the people of Israel but through the operation of the wisdom of God he blessed it. But others think that a holy angel had composed these verses, which also we ourselves approve, although we detect in them something from the books of the gentiles. But whoever was their author..."

75 The basis of this idea is found as early as Paul's letter to the Romans, and then again in Aug. Trin. XIII, 12, where he says that the demons also receive their power from God: Nec hominem a lege suae potestatis amisit quando in diaboli potestate esse permisit, quia nec ipse diabolus a potestate omnipotentis alienus est sicut neque a bonitate. Nam et maligni angeli unde qualicumque subsisterent vita nisi per eum qui vivificat omnia?, and also in Gregory the Great's Moralia in Iob, which was then adopted by Isidore of Seville in his Sententiae.

76 The reading of Roma, BV, E 5, f. 276v; cf. Hilka (1934-1937: 13). 
The biblical quotations are relevant to the commentator's argument. The passage from 1 Kings brings the paradox of the existence of a spirit that is both evil and comes from God, which is then explained through the division of the spirit's (evil) will and (good) ability. The biblical example of Balaam (Numbers 24-26) aptly supports the case, showing that our poem is not the first and only occasion when an author's will diverged from the actual result through the power of God. In this explanation, the devil's evil will is overcome by God's power. At the same time, the commentator mentions also the unproblematic possibility that the author of the poem was an angel, and he seems happy to drop the authorship argument and move to discussing the poem itself.

Within the "novelistic" commentary it is explained that a diligent but not very smart pupil was unable to satisfy his master's request and write verses using the assigned words. While he was crying, a demon appeared and promised to fulfill the task in exchange for the pupil's soul:

Erat quidam puer adolescens in scolis studiosus sed ingenii tardioris adeo ut vix unum facere posset in die versiculum. Quem magister suus crebro verberans sed crebrius increpans magistrali iure a discipulo exigebat versuum pensionem. Quadam vero die cum idem iuvenis secreto quodam sedet in loco et de data sibi a doctore materia componere vellet carmina nec valeret premissis gemitibus in lacrimis resolutus se de sua duricia flens et eiulans increpabat. Cumquam talibus se lamentis afficeret et dolore pre nimio capillos suos conturbatus evelleret, apparuit ei quidam vultu terribilis. Erat enim dyabolus causamque tristicie sciscitatus, id ab eo responsi accepit quod supra retulimus. Cui Satan: "Si adquiescere," inquit, "consilio meo volueris, per me omnium peritiam arcium celerrime consequeris." Quid plura? Credidit ille diabolo suggerenti seque illi ex integro mancipans desideratam quidem percepit scientiam, sed infelix suam perdidit animam. ${ }^{77}$

"There was a young boy diligent at school but of slower talents, and that to such a degree that he was hardly able to create one verse a day. His teacher was frequently beating him, but more frequently rebuking him, by the teacher's right, he required from the pupil a payment of verses. And one day when this youth was sitting in some secret place and wanted to compose poems from material given to him by the master, but was unable to do so, he, after sighs, broke into tears crying over his hardships and lamented. And while he was lamenting in this way and troubled by excessive anguish he tore his hair out, and someone with a frightful face appeared to him. In fact, it was the devil and, enquiring about the cause of his sadness, he heard from him in response what we narrated above. Satan says to him: 'If you wish to assent to my advice, you will obtain through me knowledge of all arts most quickly.' What more? He believed the suggestions of the devil and giving himself to him entirely, he received the desired knowledge but, miserable, he lost his soul."

Thus, in this case, the fact that the contents of the poem are in line with Christian beliefs instead of being demon's deceits, is rather the mark of Satan's double victory: it is precisely by reading the verses he got from Satan in exchange for his soul that the unfortunate pupil realizes his mistake.

Finally, in the so far unknown "exegetical" commentary the author suggests that the devil sometimes tells the truth because if he always lied, no one would believe him. In this way, the devil is able to confuse people more easily:

77 Transcription based on Zwettl, SB, 355, f. 106r; cf. Hilka (1934-1937: 6-7). 
Sed forte queritur quomodo ille qui in veritate non stetit, quia mendax est et pater eius videlicet mendacii, aliquando vera loquatur. Ad quod dicendum, quia quotiens alieni aliquid, id est veritatis, loquitur - de propriis enim mendacium loquitur - hoc non ad consultionem, sed ad faciliorem facit audientium deceptionem: quatinus vera aliquando loquens, etiam in falsitate credatur. ${ }^{78}$

"But one might ask how the one who did not stay in truth [i.e. on the side of the truth] because he is a liar and the father of lies, could sometimes speak the truth. To which it must be said that sometimes he says something true about the matters concerning others, but of his own matters he indeed lies. He does not do so in order to give advice but in order to deceive his audience more easily, because by sometimes saying the truth he can also be trusted in falsehood."

Thus, in each of the three cases the devil's authorship is harmonized with the Christian content of the poem, each time in a different way but each time the proposition is coherent and logical. Each of these justifications is creative and seems to reveal sincere interest in solving the issue. The traditional stereotype of the devil is maintained - he is witnessed here to promote Christianity either because the stronger God made him do so, or at a point when his victory is secure just to torture the caught soul some more, or because he is a sophisticated trickster who likes to play.

\section{The exegetical method and the commentators' hesitations}

Only the author of the "exegetical" commentary comments on his method of explanation: refering to a verse from Psalm 41 (42), abyssus abyssum invocat ("deep calls for the deep"), he explains that the difficulty of the verses calls for explanation through the Scripture:

Versus itaque diaboli magna, ut superius dictum est, misteria continentes, auctorem execrantes recipimus quorum exponere non ex mei tenuitate, sed ex magistrorum quibus Deus revelavit traditione auxiliante Deo explicabo, ut lucerna hactenus sub modio ignorantie occultata, exposita super intelligentie candelabrum utilitati luceat eam intuentium. Hoc autem opusculum 'Abyssus abyssum invocat' appelari volui; istorum etenim versuum profunditas ad suam explanationem Sacre Scripture invocat profunditatem. ${ }^{79}$

"Abhorring their author, we accept the verses of the devil containing, as mentioned above, great mysteries, the meaning of which I will explain, with God's help, not from my simplicity but from the tradition of the masters to whom God revealed, just as a lamp so far hidden under the measure of ignorance exposed on the lampstand of intellect will shine to the usefulness of those who look at it. So I wanted to call this opuscule 'Deep calleth the deep' [Ps 41, 8], because the depth of these verses calls for explanation of the depth of the Sacred Scripture."

And indeed, throughout the commentary, he is referring to the Bible. This passage is also an explicit recognition of the obscurity of the verses.

78 Charleville-Mézières, BM, 117, f. 2r.

79 Charleville-Mézières, BM, 117, ff. 2v-3r. 
The other commentators do not present any kind of a specific method. It seems that they simply try to decode the verses as well as they can. On several occasions they show hesitation about their proposed solutions. This could be a typical topos of captatio benevolentiae, but also a sincere reaction to the obscure poem. In the "apologetic" commentary, for example, the author says: et tamen recta sunt, nisi fallor, que in eis dicuntur ("and yet it is correct, if I am not mistaken, what is told in them"). ${ }^{80}$ The same author shows uncertainty when introducing the second authorship option:

Aliis tamen visum est quod angelus sanctus hos versus composuerit, quod et nos ipsi approbamus, licet quedam ex libris gentilium in eis cernamus. Sed quicumque eorum auctor sit... ${ }^{81}$

"But others think that a holy angel had composed these verses, which we ourselves also approve, although we detect in them something from the books of the gentiles. But whoever was their author..."

And again, slightly below:

Quia ergo sensum historicum versuum breviter prelibavimus, iam de hiis, prout Dominus dederit, tractare incipiamus. Ait namque eorum compositor, quisquis ille fuerit... ${ }^{82}$

"Because we have thus briefly foretasted the historical sense, we will begin to treat them, as the Lord allowed. For their author, whoever he was, says..."

In several manuscripts the "novelistic" commentary contains a longer introduction with a dedication to a certain father Hugo that addresses the problem with interpretation very explicitly, and so I quote it here in full:

Expositurus vobis, pater Hugo, versiculos quos humani generis inimicus fecit cuidam ut dicitur puero multum fateor hesitavi hinc considerans mei parvitatem ingenii, inde pondus perpendens opusculi: opusculum dixerim propter brevitatem verborum, pondus autem ob difficilium obscuritatem enigmatum. Nemo enim, quamlibet sapiens, versus istos enodare valeret, nisi prius eos ille, qui revelat misteria, spiritus explanaret aut, qui fecit illos, per se ipsum dyabolus explicaret. Eos ergo non ut volui, sed ut potui vobis exposui, nam ipsorum expositionem prolixam, quam magister quidam a quodam nigromantico clerico, non parvo emerat precio, semel tantum vidi et legi, vix eodem concedente magistro. Sed quia eam ferventi animo percurri sententiarum summam tenaci memorie commendavi. Rogo denique, ne urbana prudentia vestra impolitum et incultum sermonem abhorreat, sed que simplici proferuntur eloquio, diligenter attendat. Neque enim inperitus ego et urbanitatis expers homuncio tullianam ualeo propinare facundiam, qui propter inopiam codicum divinorum quos ardenti studio legerem si haberem grande mihi parientem fastidium cotidie musito psalmodiam. Vobis igitur inputetur, quicquid hic vitiosi invenitur sermonis, quia me conscientia vestra teste, ut opusculum istud inciperem, compulistis. Et licet me a legentibus non ambigerem irridendum, malui tamen petitionibus vestris annuere quam superbie, que origo est omnium malorum, execrabilem noxam incurrerem. ${ }^{83}$

80 Roma, BV, E 5, f. 276v; cf. Hilka (1934-1937: 13).

81 Roma, BV, E 5, f. 276v; cf. Hilka (1934-1937: 14).

82 Roma, BV, E 5, f. 277r; cf. Hilka (1934-1937: 14).

83 This part is missing in Zwettl, SB, 355. This is reading found in Kraków, BJ, 126, Praha, Kap, A 79/4, and Wien, ÖNB, 1062, cf. Hilka (1934-1937: 5), who does not know Kraków; in Darmstadt, HB, 947 
"Father Hugh, I confess that I hesitated much when I was about to explain to you the little verses which, as it is said, an enemy of the human race made for some boy. Here I considered the smallness of my talent, there I examined the weight of the opuscule. I have said opuscule for the brevity of the word, but weight for the obscurity of difficult enigmas. Indeed no one, however wise, would manage to elucidate these verses unless the spirit that reveals mysteries explained them to him, or the one who made them, though himself the devil, explicated them. Thus, I did not explain them to you as I wished but as I could, since I have only once seen and read their detailed exposition, which a certain master bought for not a low price from a certain nigromantic cleric, the master hardly allowing it. But because I ran through it with a fervent mind, I stored the summary of the sentences in [my] firm memory. I only wish that your urban sagacity does not shudder at [my] rough and uncultivated speech, but considers attentively what is narrated in a simple style. Indeed, I, an inexperienced dwarf lacking elegance, do not succeed at approaching Tullian eloquence. Due to the lack of divine codices which I would have read with ardent interest had I possessed them, everyday I mutter psalms bringing me great nausea. So whatever is found faulty in this speech should be attributed to you, because, be your consciousness the witness, you urged me to begin this opuscule. And even if I do not avoid being mocked by the readers, I preferred to acquiesce to your wishes than to run into the accursed crime of pride, which is the origin of all evils."

On the one hand, apologizing for the roughness of style and the lack of learned elegance, urbanitas, as well as calling oneself a dwarf and appealing to the reader's benevolence are familiar commonplaces. On the other hand, it is unusual, and certainly not part of the captatio benevolentiae topos, that the author blames father Hugo (rather than himself) for all the text's flaws. Several unique features appear here: the verses are described as brief but heavy due to their obscurity, which may be explained only by the divine spirit or by the devil who composed them. The origin of the commentary itself is most curious, too: it is not simply the creation of its author but his attempt to remember the text's explanation that he was able to see by another master, who bought it from a necromantic who, as it is implied, probably obtained it from a devil. The fact that the author could see the commentary only briefly (vix eodem concedente magistro ["the master hardly allowing it"]) adds another topos: vague memory of something precious but elusive. ${ }^{84}$

The commentators thus try hard to explain the obscurities of the verses, often providing several possibilities. If they are not sure about the interpretation, they see the fault in themselves, not in the text; they do not question the Christian message behind.

\section{Physical context: the codex contents}

Whether accompanied by commentaries or not, the Versus are always placed into another context - the context of other texts copied in the same codices. As long as the codex was written at one time and place, or at least bound already in the Middle Ages, these may suggest where a particular text was thought to best fit. However, utmost care is

it is substantially shortened.

84 Since the "exegetical" commentary shares some features with the "novelistic", it seems theoretically possible that the commentary that author of the "novelistic" commentary saw and attempts to reconstruct was the "exegetical" commentary. This seems very unlikely - the author of the "novelistic" commentary would have a very bad memory indeed. 
to be taken to avoid overinterpretation. For example, there is a curious codex Bruxelles, $\mathrm{BrB}, 5387-96$ (with the "apologetic" commentary), which is actually a kind of a draft book of Guibert of Gembloux, who later revised and polished a number of his works included here. Guibert was very actively promoting St. Martin of Tours, ${ }^{85}$ and also this codex contains several texts linked to St. Martin. Just preceding the Versus we find a part of Historia Francorum by Gregory of Tours, which he also used later. Yet, as far as the Versus are concerned, they do not seem to be related to the other texts in the volume, nor does Guibert appropriate it in his later writings. It is thus possible that Guibert simply saw the Versus in the model from which he copied the Historia Francorum, and included it in his book out of simple curiosity. ${ }^{86}$

In most other occasions it is nevertheless possible to see some transmission patterns. Beside the typical and expected context of biblical exegesis, liturgical and other practically useful religious texts, three basic types of this physical context emerge for the Versus maligni angeli: history, prophecy, and literature in the sense of fiction or "belles-lettres." To my knowledge the full poem is never found together with magic or medical texts.

\section{a) Exegesis, liturgy, and practical religion}

This is not a true category but simply a group comprising a variety of texts closely linked to Christian religious practice. There are, on the one hand, learned biblical commentaries. In two early manuscripts, our verses are added to works of Gregory the Great, Moralia in Iob and Homilies to Ezekiel. ${ }^{87}$ There are also, for example, Origen's homilies, ${ }^{88}$ Song of Songs commentary by Gilbert of Stanford, ${ }^{89}$ Psalter commentary by frater Thomas Gualensis (or Wallensis or Willes, d. 1255), ${ }^{90}$ works by St. Cyprian, ${ }^{91}$ and, in several cases, exegetical works by Herveus Burgidolensis, a possible author of the "apologetic" commentary. ${ }^{92}$ The commentators of the Versus, as was shown in detail above, used the established methods and form of Christian exegetical tradition.

On the other hand, there are less learned but more common texts linked to religious practice, such as an excerpt from Honorius Augustodunensis' Elucidarium, ${ }^{93}$ Odo of Morimond's Tractatus de spirituali edificio, ${ }^{94}$ prayers, sermons, theological and exegetical notes, and moral treatises. There are several treatises by Hugh of St. Victor: De sac-

85 The links to Tours within the transmission of the Versus are actually quite frequent: the oldest known manuscript of the apologetic commentary (Tours, BM, 257) is provenient from the St. Gatien cathedral of Tours. In Heiligenkreuz, SB, 11 and Zwettl, SB, 13, selected miracles by Gregory of Tours are found immediately after the Versus with the "moral" commentary.

86 There is only one more text in the codex with no direct connection to Guibert of Gembloux, namely Arnold of Bonneval's Tractatus de verbis Domini in cruce positi.

87 New York, PML, 765, and Bourges, BM, 105. The link might be still stronger: the author of the "exegetical" commentary uses the list of virtues and vices as it appears in Gregory the Great's Moralia in Iob.

88 In Paris, BnF, lat. 1628.

89 In Laon, BM, 23 (Guglielmetti 2002).

90 As the main contents of Praha, Kap, A 79/4. Thomas was in close contact with Robert Grosseteste, and was active in Lincoln, Leicester, Oxford, and Paris before becoming the bishop of St. David's in Wales.

91 Tours, BM, 257.

92 Wooster, Roma, BV, E5, and the lost Pontigny copy.

93 The main contents of Paris, BnF, 2877A, followed by a note on the three Maries and the Versus.

94 The Versus are copied just after this text in Zwettl, SB, 355. 
ramentis christiane fidei $i^{5}$ and six shorter ones (De meditatione, De iudicio veri et boni, De quatuor voluntatibus in Christo, and De verbi incarnatione, De potestate et uoluntate dei, De unione corporis et spiritus) ${ }^{96}$. In Darmstadt, HB, 947 (XIV), the Versus are followed by brief expositions on Pater noster, Credo, and Quicumque vult (The Athanasian Creed), the most widespread texts pertaining to Christian worship. München, BSB, clm. 18921 is a very miscellaneous codex with a number of brief texts on saints, virtues and vices (but also on chess or interpretation of dreams). We often find a variety of brief excerpts and remarks in vicinity of the verses, curiously notes on excommunication immediately following the verses in a codex that includes primarily Augustine's and Pseudo-Augustine's texts, ${ }^{97}$ or Explicatio excommunicationis ejusque fautoris immediately after the verses in a miscellany with Philo's Antiquitates Biblicae, ${ }^{98}$ or the De nequicia heretici just after the verses in two related codices containing primarily the Magnum Legendarium Austriacum for January-March. ${ }^{99}$ Actually, legends - a type between practical religion and fiction - reappear, too: besides these two full legendaries, the Versus follow the Life of Mary Magdalene in München, BSB, clm. 2561, and was apparently included in a Tegernsee passionale just after a legend on the translation of the same saint. ${ }^{100}$ In München, BSB, clm. 23390, Breviarium apostolorum immediately follows a fragment from the "novelistic" commentary. A great part of Paris, BnF, n. a. lat. 1543, is concerned with saints' relics.

These and similar texts were much widespread throughout the Middle Ages and do not seem to offer a distinguished easily interpretable context for the Versus. Yet, they remind us that majority of medieval Latin textual production was concerned with Christian ethics: defining and discussing good and evil in all possible contexts within the Christian framework, that is, with frequent reference to the Bible - most obscure but also most authoritative text. The Versus maligni angeli fit very well within this tradition: it is obscure but provides another ("external") evidence on the fight between good and evil, and directly urges the reader to make the correct choice.

Among these texts, a subgroup of brief obscurities accompanied by an elucidation can be discerned. These usually immediately precede or follow the Versus. That is the case of another brief poem connected to the devil (Parabola diaboli) in Praha, Kap, A 79/4,101 and especially of the Cena Cypriani with Herveus' commentary. Although the Cena is substantially longer, its commentary has the same formal features of the Versus commentaries: Herveus explicitly confesses when he hesitates or is at a loss about the interpretation but he never doubts that there is a Christian meaning behind the text. These texts form a very relevant context of curious but appropriable opuscules that can be used for religious or moral instruction.

\footnotetext{
95 In Karlsruhe, BLB, 12; the Versus are added at the end of Hugh by a different hand, though.

${ }^{96}$ In Charleville-Mézières, BM, 117.

97 In Freiburg, UB, 9.

98 Salzburg, SB, A.VII.17.

${ }^{99}$ Heiligenkreuz, SB, 11 and Zwettl, SB, 13.

100 As states the note in München, BSB, clm. 18921 quoted above.

${ }^{101}$ Inc. Hec autem parabola diaboli est ad quendam clericum in Ungaria nunciata. Hac in nocte passus...
} 


\section{b) History}

The verses are found together with chronicles, too, namely Historia Karoli Magni by Pseudo-Turpin, ${ }^{102}$ with several Flemish (namely that of Sigebert of Gembloux, d. 1112) and crusade chronicles in Paris, BnF, n. a. lat. 1543, just after Landulphus Columna's Breviarium historiale (from ca. 1320) in Vatican, BAV, Ottob. 1758, or just after an excerpt from the Historia Francorum by Gregory of Tours in Bruxelles, BrB, 5387-96. Although this connection is not easy to interpret, the possibility remains that the Versus describe an actual event. ${ }^{103}$ This is the supposition presented in the revised edition of the Du Cange Glossarium, which, when commenting on the poem, says:

...arbitror cenigmaticos esse versus, quibus ad aliquam historiøe illius avi partem alluditur. Certe his versus: 'Praelatura tibi jam constat munera plura,' proelatum aliquem simoniaca labe infectum arguere videtur. ${ }^{104}$

"...I consider them to be enigmatic verses, through which an allusion is made to a certain part of the history of that time. Certainly the verse: 'already your office brings many gifts', seems to argue that a certain prelate is infected by a simoniac fall.”

In the historical sources, however, I have not found a close parallel to the Versus. Only within the description of the Battle of Soissons (June 15, 923) in the account of Richer of Saint-Remi (Richerus Remensis, 10th c.), there is a clause reminiscent of the Versus maligni angeli:

Et post hęc, cum episcopis virisque religiosis qui aderant, montem loco oppositum conscendit, ubi etiam est basilica... ${ }^{105}$

"And afterwards, together with bishops and religious men who were there, he ascends the mountain opposite to that place, where there was a church..."

Here, the priest goes to pray before the battle, which, as D. S. Bachrach describes in this very context, was apparently a usual procedure:

"The importance of battlefield prayers for raising the spirits of the troops should not be underestimated. It was hardly coincidental that after King Charles III of France delivered a rousing oration to his troops on the eve of the battle of Soissons in June 923, the bishops and other clerics serving with his forces ostentatiously withdrew to the nearby high ground where a basilica dedicated to Saint Genevieve was located. Richer emphasized that they went there to help prepare for the battle, almost certainly by praying to God to intercede on behalf of their soldiers. The fact that these prayers could not be heard by Charles' men was less important than their almost certain knowledge of what the clerics were doing." ${ }^{06}$

If any relationship exists to this event, then the reading Oppositum montem conscendere cernis orantem (opposite the mountain you note the praying one descending), rath-

\footnotetext{
102 In Besançon, BM, 862; cf. Paris (1865) and Robert (1891: 213).

${ }^{103}$ History is in some aspects not far from prophecy; see Southern (1972).

${ }^{104} \mathrm{Du}$ Cange (1840: 212) (revised edition by Benedictines of St. Maur).

${ }^{105}$ Richer. Rem. Hist. I, 45 (ed. Hoffmann 2000: 78). The work survives in an autograph manuscript, now Bamberg, SB, Misc. Hist. 5, where we find this passage on f. 11v.

106 Bachrach (2003: 78).
} 
er than Orontem (the Orontes River), would be the original one. None of the surviving manuscripts, however, appear together with Richer's chronicle, nor with any other chronicle describing a similar event. ${ }^{107}$

In this case, we face again the problem of meaning: the poem might have been written as an encoded narrative of a battle and gradually corrupted to greater degree of incomprehensibility during its transmission, or, on the other hand, it might have first appeared as an almost incomprehensible example of the devil's language, and the meaning was gradually added to it during the transmission. If the former was the case, it would suggest that the formula Amaratunta tili... was used also as a battle cry for encouraging the troops or scaring the enemy. In any case, the poem might have been influenced by Richer's chronicle, or Richer might have used the image from the poem in his chronicle, or the two might be completely unrelated. Unless new data are discovered, this question cannot be satisfactorily answered.

\section{c) Prophecy}

The context of a prophecy comes to the fore especially in the manuscripts in which the "apologetic" commentary is ascribed to Joachim of Fiore and transmitted among other prophetic texts. ${ }^{108}$ There are other texts near the Versus that are concerned with the future events, e.g. München, BSB, clm. 2561 includes Prognosticon futuri saeculi (the first Christian systematic treatise on eschatology) by Julian of Toledo (Iulianus Toletanus, 652-690) together with the "moral" commentary, but these are not real prophecies.

Prophecy is a type of obscure text par excellence; it is a result of the communication of divine knowledge through a medium (a prophet) in such a way that its meaning is obscure. As text, prophecy is surely not a genre in itself, it may be embedded into a variety of other genres. It is not necessarily a narrative either, as there are purely descriptive prophecies as well. Are there, then, any common aspects or characteristics of the literary type?

Intuitively, one might claim that prophecy refers to the future, but this is in fact not true: the future events (culminating in the Last Judgement) are known to medieval Christians thanks to the biblical Revelations, and thus prophecies in fact rather offer a key for understanding the past and the present. Another notion is that prophecy offers a type of knowledge not normally accessible to mortals; however, many prophecies are interpreted as re-confirming the coming of Christ, information that would have been repeated to medieval Christians almost daily. Another possible characteristic is the extraordinary circumstances of the origin of a prophecy that serve to authenticate a text as prophecy in the first place. For example, a prophecy might be legitimized by a specific person (medium) who is in touch with the divine, or half-human, or appears on the border of society in some way. Alternatively, it may be authorized through the specific state of the medium (sleep, half-death, possession by spirits, etc.), or by its extra-terrestrial origin (e.g. a let-

${ }^{107}$ Another possibility, which would make the poem refer to reality, was suggested to me by Cristian Gaspar. The poem could be a description of the city of Antioch, through which the Orontes River runs and where a head is carved into the mountain over the city. Lanx could then be lancea (i.e. a lance rather than a plate) referring to Christ's lance that was "found" in Antioch.

${ }^{108}$ Basel, UB, A.II.25, Ivrea, BC, VI (74), Madrid, BN, 9731, and the apparently lost Peñiscola Castle, no. 134. This subchapter was already partly published in Doležalová (2016). 
ter from heaven, or a text that comes from "the outside"). Frequent are also texts from different cultures which are then appropriated to reinforce the ideas to be promoted (for example, even the pagans are proven to speak of Christ). Yet this "authorization" does not necessarily have to leave textual traces at all - it may depend solely on the identity of the author, and thus be assumed. Another aspect is the use of the text, which may be political (linked to a power struggle), philosophical and spiritual, or meditative and related to personal salvation. ${ }^{109}$ Yet, again, the use of it is not necessarily an obvious part of the text - these aspects may be reflected in the style but cannot be applied as reliable criteria for categorizing the texts.

Thus, I would like to claim, the single distinguishing feature of prophecy as text is its obscurity, ambivalence or ambiguity: the possibility for different interpretations that invite explanation. This feature is linked to a general aspect of prophecy that does not help to define the type but rather illustrates that its classification as prophecy is based on its reception: the text is complemented by its explanation. In a way prophecy fully exists only when it is "activated", which is to say interpreted, explained or perhaps rather manipulated to fit where we want it to fit. Thus, we encounter "failed prophecies" that begin to operate as leisure literature, ${ }^{110}$ or brief obscure texts which function as riddles, or do not have any role at all until found and expounded on as prophecies.

All this is most relevant for Versus maligni angeli. The link to meditation and personal salvation is not unheard of, nor is the connection to converting heretics. The references to classical culture, Oedipus and Clio, are surprisingly integrated without hesitation, perhaps exactly because it was common for prophecies to stem from other cultures. Most importantly, the "external origin" troubling the commentators fits perfectly in this context. Versus maligni angeli thus indeed operate as a prophecy, and, when transmitted together with the "apologetic" commentary, it resembles, in several aspects, Joachim de Fiore's De prophetia ignota. Matthias Kaup discusses both the texts, taking for granted that our Versus are actually a prophecy. ${ }^{111} \mathrm{He}$ also surveys strategies in creating new prophetic texts, discussing the possible sources - God, demon or pagan - and stresses their frequently long life and a number of re-interpretations: again, features characteristic for the Versus, too.

Could Versus maligni angeli have been a prophecy? The little we can infer about its origin does not seem to suggest it - placing the "apologetic" commentary among other prophetic works by Joachim de Fiore is certainly a later phenomenon (the link to Herveus Burgidolensis is earlier and stronger). Yet, as discussed above, no universal features for a prophetic type of writing exist. Prophecy might simply be defined as an obscure text ready to be picked up and (re)interpreted in a new way, possibly in order to serve for reinforcing Christian dogmas and motivating Christians to change their behavior to take part in the salvation history. This seems to be its contextualization within Basel, BU, A II 25, where the "apologetic" commentary is attributed to Joachim de Fiore, yet not transmitted

\footnotetext{
${ }^{109}$ Regarding circulation in a monastic and clerical environment, Holdenried (2005: 167) writes: "In these surroundings eschatological beliefs were not synonymous with conjectures about the imminence of the End. Rather, devotional practices encouraged reflection upon an individual's chances on the Day of Redemption." Sibylla Tiburtina is, in Holdenried's (2005: 168) conclusion, "an aid for devout reflection... tied to the monastic preoccupation with personal eschatology."

${ }^{110}$ Cf. Pedretti (2011).

111 Kaup (1998: especially 85-144).
} 
among his works but mostly with texts relevant to the council of Basel (1431-1449) or contemporary with the event. ${ }^{112}$ The Versus are immediately preceded by a disputation of a Jew and a Christian, and followed by an excerpt from William of Paris' ${ }^{\prime 13}$ De universo on the nature of demons. The few texts concerned with the last things such as Heinricus de Hassia's ${ }^{114}$ De ultimo statu ecclesie et fine mundi ${ }^{115}$ function exactly to reinforce the idea of the present crisis. Understood in this broad meaning as an obscurity arousing curiosity of the reader to be subsequently explained to confirm Christian dogmas and approach to the meaning and framework of history, Versus maligni angeli certainly are a prophecy.

\section{d) Literature}

In several codices, and especially in codices from unknown but probably not monastic environments, Versus are copied together with truly literary texts. Of these, most frequently recurring are medieval language games. Twice we find them together with the playful poetry of Marbode of Rennes (1035-1123). In Edinburgh 18.6.12 (XII-XIII, Thorney), our verses are immediately followed by Marbode of Rennes' poem usually called Vas fractum:

$\begin{array}{ll}\text { Porticus est Rome, } & \text { quo dum spatiando fero me } \\ \text { Res quaerendo novas, } & \text { inveni de saphyro vas } \\ \text { Institor ignotus, } & \text { vendebat cum saphyro thus, } \\ \text { Thus socius noster } & \text { tres emit denatorios ter } \\ \text { Vas tribus et semi } & \text { solidis ego prodigus emi, } \\ \text { Hoc inconcussum } & \text { dum tollere sollicitus sum } \\ \text { Pro cofino mundo } & \text { de viminibus pretium do } \\ \text { Ponitur introrsum } & \text { sanum vas inde memor sum, } \\ \text { Extrahitur fissum, } & \text { tristis, miser inde nimis sum. } \\ \text { Inter convivas } & \text { magni foret hoc pretii vas } \\ \text { Si foret allatum, } & \text { sicut positum fuerat tum. }\end{array}$

We read the same poem in Wien, ÖNB, 2521, although a little further after the Versus. ${ }^{117}$ One immediately notices a simple funny story narrated with special attention to rhyme. It is not a very artistic creation, but rather the result of a play with words. In the Edinburgh manuscript, further poems in a very similar style follow: they are entitled differentiae, and always juxtapose two homonyms of different meanings. They begin:

$\begin{array}{ll}\text { Parce tuis verbis. } & \text { Nunquam veniat tibi ver bis. } \\ \text { Semper inops vivas. } & \text { Cur aufers hoc mihi vi vas? }\end{array}$

112 There are also text on the Hussites including the manifest of Tábor from 1430 and reactions to it. Cf. Bartoš (1931a: 43; 1931b: 256).

${ }^{113}$ Or William of Auvergne, bishop of Paris from 1228, d. 1249.

${ }^{114}$ Heinrich of Langenstein, 1325-1397.

${ }^{115}$ Also called Planctus ecclesiae, deals with the Papal schism.

116 Walther (1959: no. 14284). PL 171, 1685 (as poem no. 59). See also Werner (1905: 93, no. 216).

${ }^{117}$ F. 41r. It is included also in Paris, BnF, lat. 152, f. 35, Zürich, ZB, C.58, Wien, ÖNB, 143 (f. 15v, where there are also pseudo-Virgil's poems, f. 14r, and versus et quidem undecim disticha by Gregory the Great on ff. 13v-14r).

${ }^{118}$ F. 35r. This text does not seem to be edited yet and I am not aware of any other manuscripts. 
The codex opens with an originally independent part with Persius' satires, Avian's fables, Cato novus, or exemplary verses from Horace, and further in it we find a playful epitaph, epigrams, and riddles (including Symphosius' Aenigmata). ${ }^{119}$ In Praha, Kap, B 62, our verses immediately follow John of Garland's ${ }^{120}$ Carmen de equivocis, a very similar type of poetry.

Another link to literature is the "novelistic" commentary itself: first, it tells a very novel-like story (the pact between student and devil appears during the Middle Ages also in Caesarius of Heisterbach's Libri miraculorum ${ }^{121}$ or in Gesta Romanorum, ${ }^{122}$ for example). Second, within the story, the poem is actually a school exercise: the student is assigned particular (supposedly difficult) words from which he is asked to make a poem (de data sibi a doctore materia). Composing a poem in this way (although here the pupil fails and the devil does it for him) resembles language games practiced by Marbode of Rennes or John of Garland. Thus, even if our verses were not originally a literary creation, a kind of a riddle, an enigma, or a play with words, these forms became a suitable context for their transmission.

Other reappearing literary context is that of the literature of Classical and Late Antiquity. Beside the Edinburgh manuscript mentioned above, two copies of the verses with the "apologetic" commentary include a selection of mainly Late Antique authors such as Proba's cento, Prudentius, Macrobius' commentary to Somnium Scipionis ${ }^{123}$ or Cassiodorus, Symmachus, Boethius' De Trinitate, and Sidonius Apollinaris. ${ }^{124}$ Several codices are at least partly literary ${ }^{125}$ - for example in Bruxelles, BrB, 10038-53 (XIII), the Versus are immediately followed by Collocutio invectiva ovis et lini, a text by a Flemish author; or there is Innsbruck, UB, 355 (from 1334), an encyclopaedic miscellany in Latin and German on various types of knowledge (e.g. the names of fish, birds, and other animals, astrology and alchemy, colours, recipes), which has also fictitious letters of Pharaoh to Joseph. Another unique and noteworthy manuscript is Kraków, BJ, 126 from the fifteenth century (fig. 6), a miscellany with texts linked to the Council of Basel, including works of contemporary Italian humanists as well as by Poles who appearently brought it back from there to Poland. ${ }^{126}$ The Versus appear within Pseudo-Alexander's dialogue and correspondence with Didymus but could also be linked to some of the anti-heretical texts included in the codex. It is not difficult to imagine that some of these codices were used at schools but since we lack explicit evidence on this point, the school use of the Versus remains a mere suggestion.

In a very specific manuscript, Wien, ÖNB, s. n. 12702, written in 1444 by Johannes Meerhout, an Augustinian canon at Korsendonk (d. 1476), the verses are completely integrated with excerpts from Virgil accompanied by Meerhout's explanatory notes and are

\footnotetext{
119 Vernet (1948).

${ }^{120}$ English grammarian and poet, ca. 1180-1252, lived mostly in France.

${ }^{121}$ Caesar. Heisterb. Mirac. II, 22.

122 Gesta Roman. 163.

123 Bruxelles, BrB, 978.

124 Montpellier, BM, H.4.

${ }^{125}$ Less relevant for our discussion is Glasgow, UL, 205, where the verses are a sixteenth-century addition to a twelfth century codex with the works of Seneca.

126 This codex serves as an apt example of the intellectual and cultural exchange beyond the theological debate that must have taken place during big medieval councils.
} 


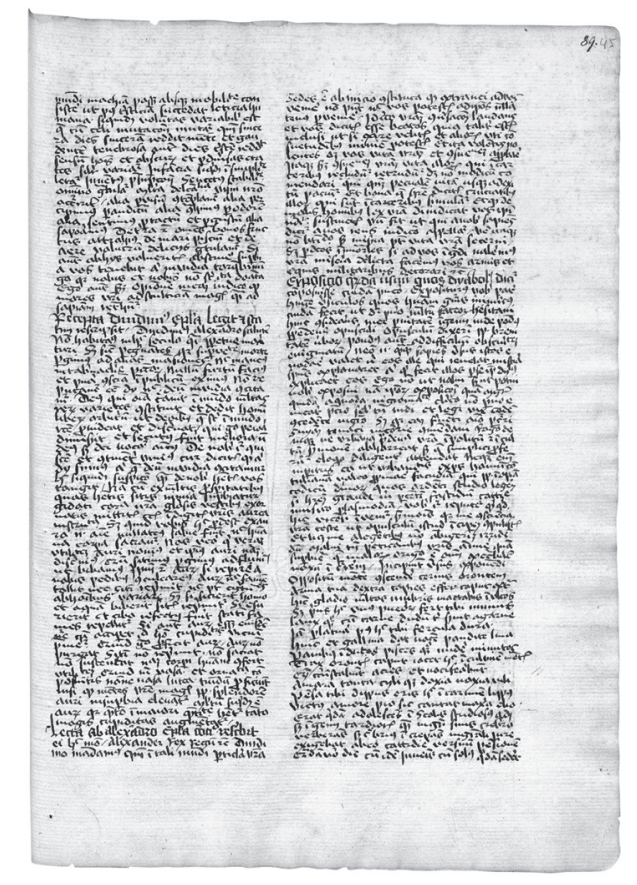

Fig. 6: Ms. Kraków, Biblioteka Jagiellońska, 126, f. 45r; the Versus with the "novelistic" commentary within Pseudo-Alexander the Great's correspondence with Didymus.

not distinguishable from them in any way. Marc Laureys, who analyzed Meerhout's comments, noted that although our verses are not really connected with Virgil, they contain a number of rare words and may have aroused Meerhout's interest for that reason. ${ }^{127}$ The presence of a general note - istos versus diabolus fecit cuidam puero timenti verberari makes it seem influenced by the "novelistic" commentary. The notes themselves do not explain the meaning of the text with the exception of one concrete word, Clio. A strong classical link is made in quoting Virgil, Servius, and Martianus Capella in this context:

Clio debet esse, de qua Virgilius in $4^{\circ}$ Georgicorum s[cribit]: Altera tum primos lucine experta labores, Clioque et Beroe soror, Oceanitides ambae, ambae auro, pictis incinctae pellibus ambae [Verg. Georg. IV, 340-342]. Servius: Notanda autem figura honestissima facta ex repetitione sermonis.

Greco dyan, quod est lux vel claritas.

M[artianus Capella:] Dione Venus a matre sic dicam et dicitur quasi duo nectans. ${ }^{128}$ Vide summam ${ }^{129} 13^{\circ}$ : sacra Dione a.

\footnotetext{
127 Laureys (1992).

128 Westra, Kupke (1998: 46): Unde Dione dicitur a 'dian', quod est claritas, a quo et dies dicitur, licet etiam Dione dici possit quasi duo nectens, eo quod Venus in duorum commixtione gaudet.

129 Perhaps Summa super Priscianum is meant where this also appears.
} 
However, making the Versus part of Virgil and stressing the Classical rather than the Christian tradition in its contextualization seems to be an exception.

\section{Contextualizing obscurity}

The hardly intelligible verses of uncertain origin discussed here may have developed around an exorcist formula. While today's reader would tend to consider the poem an insignificant obscurity, medieval reception did not place it in the margin: it survives in 37 manuscripts from twelfth to fifteenth centuries (and in at least 8 more in some distorted version) originating from various environments and areas of Europe. In addition, it attracted attention of four different twelfth-century interpreters who dedicated their energy to explain its meaning without feeling the need to justify or defend this activity.

Each commentary interprets the verses in the context of Christian ethics, either as a fight between Christ and devil, or as encouragement for preachers to fight against heretics, or an urge for Christians to avoid devil's tricks and sinning. Just like in biblical exegesis, the commentators frequently offer several possible explanations without hierarchization. Each of them devotes special attention to explaining how come a devil or a demon authored verses that actually turn the audience to the good side. Each of these justifications is creative and reveals sincere interest in solving the issue. Thus, the commentaries are, on the one hand, similar in appropriating the verses to fit the "mainstream" culture (and thus reflect and prove its "power"), while, on the other hand, they substantially differ in particularities where they reveal independent creative and associative treatments.

Only once were the verses fully integrated among writings of a Classical author, namely Virgil, and glossed on with the use of other Classics rather than the Bible. This exception might be only a seeming one, though: a very detailed study of the codex (Wien, ÖNB, s. n. 12702) was necessary to find out that the Versus are included in it. Thus, there might be other instances of similarly inconspicuously integrated copies of the Versus waiting to be noticed. ${ }^{130}$

The scrutiny of the codex contents (although several possible paths were not followed) ${ }^{131}$ enabled us to observe that the Versus were not only interpreted and contextualized in a variety of ways but also played different roles: they were a prophecy, a game with words, a moral treatise, or a simple curiosity. The fact that the text, while remaining acceptable for the Church, was appropriated in such various ways and made fit so diverse environments suggests not only that its initial place and meaning was (for whatever reason) not fixed, but also that the medieval Church was not so strict about forcing general uniformity as it is still often assumed. Although not quite in the centre of the Christian discourse, there was sufficient space provided for obscurity and the pains and pleasures of interpreting and appropriating it.

${ }^{130}$ It is also a noteworthy pattern that the better the Versus are integrated, the more difficult it is to trace it.

${ }^{131}$ For example, I have not explored here the link to the excerpts from Aristotle (in Basel, Innsbruck, Praha, Kap, A 79/4, and Wien, ÖNB, 1062), which, however, seem different in each case and only a detailed scrutiny of them would reveal whether this connection is relevant. 


\section{REFERENCES}

\section{Manuscripts}

Bamberg, SB = Staatsbibliothek, Misc. Hist. 5

Basel, UB = Universitätsbibliothek, A. II. 25.

Besançon, $\mathrm{BM}=$ Bibliothèque municipale, 862 .

Bourges, $\mathrm{BM}=$ Bibliothèque municipale, 105 .

Bruxelles, $\mathrm{BrB}=$ Bibliothèque royale de Belgique, 10038-53 (978). 5387-96 (3168).

Charleville-Mézières, $\mathrm{BM}=$ Bibliothèque municipale, 117 .

Darmstadt, HB = Hessische Landes- und Hochschulbibliothek, 947.

Edinburgh, NLS = National Library of Scotland, 18.6.12.

Freiburg im Breisgau, UB = Universitätsbibliothek, 9.

Glasgow, UL = University Library, Hunterian Museum, 205 (U.1.9).

Heiligenkreuz, SB = Stiftsbibliothek, 11 .

Innsbruck, UB = Universitäts- und Landesbibliothek Tirol, 355.

Ivrea, $\mathrm{BC}=$ Biblioteca capitolare, VI (74).

Karlsruhe, BLB = Badische Landesbibliothek, St. Peter Perg. 12.

Kraków, BJ = Biblioteka Jagiellońska, 126.

Laon, $\mathrm{BM}=$ Bibliothèque municipale, 23.

Madrid, BN = Biblioteca Nacional, 9731.

Merseburg, Domstiftsbibliothek, 40.

Montpellier, BU = Bibliothèque Universitaire, Méd. H.4.

München, BSB = Bayerische Staatsbibliothek, clm. 1352.

clm. 2561.

clm. 2611.

clm. 4660 .

clm. 18921 .

clm. 23325 .

clm. 23390.

New York, PML = Pierpont Morgan Library, M. 765.

Oxford, $\mathrm{BL}=$ Bodleian Library, Digby 53 .

Paris, $\mathrm{BnF}=$ Bibliothèque nationale de France, lat. 1628 .

lat. 2877A.

nouvelles acquisitions lat. 1543.

Praha, Kap = Archiv Pražského hradu, fond Knihovna metropolitní kapituly Sv. Víta, A 79/4. B 62.

Roma, BV = Biblioteca Vallicelliana, E 5.

Salzburg, SBP = Stiftsbibliothek St. Peter, A.VII.17.

Schaffhausen, $\mathrm{MB}=$ Ministerialbibliothek, Min. 42 .

Tours, $\mathrm{BM}=$ Bibliothèque municipale, 257.

Uppsala, UB = Unversitetsbibliotek, C 228. C 377.

Vatican $=$ Città del Vaticano, BAV = Biblioteca Apostolica Vaticana, Ottobonianus lat. 1758. Pal. lat. 794.

Wien, ÖNB = Österreichische Nationalbibliothek, Pal. lat. 303.

Pal. lat. 1062.

Pal. lat. 2521 [Philol. 413].

Series nova 12702.

Wooster, Library of the College of Wooster (Special Collections), Ohio (no call no.).

Wrocław, Ossolineum, 601.

Zwettl, SB = Stiftsbibliothek, 13 . 355. 


\section{Secondary sources}

Andersson-Schmitt, M., Hallberg, H., Hedlund, M., 1991. Mittelalterliche Handschriften der Universitätsbibliothek Uppsala. Katalog über die C-Sammlung. Bd. 4. Handschriften C 301-400 [= Acta Bibliothecae R. Universitatis Upsaliensis XXVI, 4]. Stockholm: Almqvist und Wiksell International.

Andersson-Schmitt, M., Hedlund, M., 1988. Mittelalterliche Handschriften der Universitätsbibliothek Uppsala. Katalog über die C-Sammlung. Bd. 3. Handschriften C 201-300 [= Acta Bibliothecae R. Universitatis Upsaliensis XXVI, 3]. Stockholm: Almqvist und Wiksell International.

Astori, R., 2000. Formule Magiche. Invocazioni, giuramenti, litanie, legature, gesti rituali, filtri, incantesimi, lapidari dall' Antichità al Medioevo. Milano: Mimesis.

Audin, M., 1854. History of the Life, Writings, and Doctrines of Luther. Trans. W. B. Turnbull. London: Dolman.

Bachrach, D. S., 2003. Religion and the Conduct of War c. 300-1215. Woodbridge: Boydell Press.

Baehrens, W. A., 1916. Überlieferung und Textgeschichte der lateinisch erhaltenen Origenhomilien zum alten Testament [ $=$ Texte und Untersuchungen zur Geschichte der altchristlichen Literatur 42]. Leipzig: J. C. Hinrichs'sche Buchhandlung.

Bartoš, F. M., 1931a. Husitika a bohemika několika knihoven německých a švýcarských [Hussite and Czech texts in several German and Swiss libraries]. Praha: Královská česká společnost nauk.

Bartoš, F. M., 1931b. Husitsví a cizina [The Hussite movement and foreign lands]. Praha: Čin.

Beatie, B. A., 1967. 'Macaronic Poetry in the Carmina Burana'. Vivarium 5, 16-24.

Brandt, R., Fröhlich, J., Seidel, K. O., 2003. 'Obscuritas'. In: G. Ueding (ed.), Historisches Wörterbuch der Rhetorik. Band 6. Tübingen: Max Niemeyer Verlag, 358-383.

Caciola, N., 2003. Discerning spirits: Divine and Demonic Possession in the Middle Ages. Ithaca: Cornell University Press.

Castets, F., 1887. 'Vers attribués à l'esprit malin avec commentaire'. Revue des langues romanes: quatrième série $1,109-119$.

Clément, J.-F. [et al.], 1869. Histoire littéraire de la France. Tome XII. Nouvelle édition. Paris: Palmé.

Collon, M., 1900. Catalogue général des manuscrits des bibliothèques publiques de France. Départements. Tome XXXVII. Tours. Paris: Plon-Nourrit.

de Lubac, H., 1959-1964. Exégèse médiévale: les quatre sens de l'Écriture. Paris: Aubier.

de Ricci, S., 1937. Census of Medieval and Renaissance Manuscripts in the United States and Canada II. New York: H. W. Wilson Comp.

Doležalová, L., 2007. Reception and Its Varieties: Reading, Re-Writing, and Understanding Cena Cypriani in the Middle Ages [= Bochumer altertumswissenschaftliches Colloquium 75]. Trier: Wissenschaftlicher Verlag.

Doležalová, L., 2014. 'The Devil as a Christian Author? The Case of Versus maligni angeli. In: E. D’Angelo, J. Ziolkowski (eds.), Auctor et auctoritas in Medii Aevi litteris. Author and Authorship in Medieval Latin Literature. Florence: SISMEL - Edizioni del Galluzzo, 321-330.

Doležalová, L., 2016. 'Manuscript Transmission and an Analysis of the Pseudo-Joachimite Expositio versuum extraneorum' In: Gi. L. Potestà, M. Rainieri (eds.), Joachim posuit verba ista. Gli pseudoepigrafi di Gioacchino da Fiore dei secoli XIII e XIV. Roma: Viella, 201-213.

Doležalová, L., 2017. 'Measuring the Measuring Rod: The Bible and Parabiblical Texts within the History of Medieval Literature'. Interfaces: A Journal of Medieval European Literatures 4, 39-58.

Doležalová, L., Rider, J., Zironi, A. (eds.), 2013. Obscurity in Medieval Texts [= Medium Aevum Quotidianum. Sonderband 30]. Krems: Institut für Realienkunde des Mittelalters und der frühen Neuzeit.

Du Cange, C., 1840. Glossarium mediae et infimae latinitatis. Paris: Firmin Didot.

Faucon, M., 1887. La librairie des papes d'Avignon. Sa formation, sa composition, ses catalogues (1316-1420). D'après les registres de comptes et d'inventaires des archives Vaticanes. Tome second. Paris: Ernest Thorin.

Gamper, R., Knoch-Mund, G., Stähli, M., 1994. Die mittelalterlichen Handschriften der Ministerialbiblothek Schaffhausen. Zürich: Urs Graf Verlag.

Geerlings, W., 2002. 'Die lateinisch-patristischen Kommentare'. In: W. Geerlings, Ch. Schulze (eds.), Kommentar in Antike und Mittelalter. Beiträge zu seiner Erforschung. Leiden: Brill, 1-14. 
Guglielmetti, R., 2002. Gilberto di Stanford, Tractatus super Cantica canticorum. L’amore di Dio nella voce di un monaco del XII secolo. A cura di R. Guglielmetti [= Per verba. Testi mediolatini con traduzione 16]. Florence: SISMEL - Edizioni del Galluzzo.

Hagenmaier, W., 1974. Die lateinischen mittelalterlichen Handschriften der Universitätsbibliothek Freiburg im Breisgau. Wiesbaden: Otto Harrassowitz.

Heinzer, F., 1988. 'Die Handschriften der Bibliothek von St. Peter im Schwarzwald. Ein Zeugnis der Klosteraufklärung am Oerrhein'. In: K. Andermann (ed.), Historiographie am Oberrhein im späten Mittelalter und der frühen Neuzeit. Sigmaringen: Thorbecke.

Heinzer, F., Stamm, G., 1984. Die Handschriften von St. Peter im Schwarzwald. Zweiter Teil. Die Pergamenthandschriften [= Die Handschriften der Badischen Landesbibliothek in Karlsruhe X]. Wiesbaden: Harrassowitz.

Hilka, A., 1934-1937. 'Zur Geschichte eines lateinischen Teufelsspruchs (Carm. Bur. Nr. 55)'. Nachrichten von der Gesellschaft der Wissenschaften zu Göttingen. Philologisch-historische Klasse. Fachgruppe IV. Nachrichten aus der Neueren Philologie und Literaturgeschichte 1, 1-30.

Hilka, A., Schumann, O., 1930. Carmina Burana. I. Band. Text. I. Die moralisch-satirischen Dichtungen. Herausgegeben von A. Hilka und O. Schumann. Heidelberg: Carl Winter.

Hobbins, D., 2009. Authorship and Publicity Before Print. Jean Gerson and the Transformation of Late Medieval Learning. Philadelphia: University of Pennsylvania Press.

Hocker, J., 1569. Theatrum diabolorum. Frankfurt am Main: Peter Schmid.

Hoffmann, H., 2000. Richer von Saint Remi, Historiae. Herausgegeben von H. Hoffmann [= Monumenta Germaniae Historica. Scriptores XXXVIII]. Hannover: Hahnsche Buchhandlung.

Hoffmann, H., 2004. Schreibschulen des 10. und des 11. Jahrhunderts im Südwesten des Deutsches Reichs $I$ [ = Monumenta Germaniae Historica. Schriften 53]. Hannover: Hahnsche Buchhandlung.

Holdenried, A., 2005. The Sibyl and Her Scribes: Manuscripts and Interpretation of the Latin Sibylla Tiburtina c. 1050-1500. Aldershot: Ashgate.

Huxley, A., 1932. Texts and Pretexts: An Anthology with Commentaries. London: Chatto \& Windus.

Jeudy, C., Riou, Y.-F., 1989. Les manuscrits classiques latins des bibliothèques publiques de France. Tome I. Paris: Éditions du Centre national de la recherche scientifique.

Jostmann, C., 2006. Sibilla Erithea Babilonica: Papsttum und Prophetie im 13. Jahrhundert [= Monumenta Germaniae Historica. Schriften 54]. Hannover: Hahnsche Buchhandlung.

Kaup, M., 1998. De prophetia ignota. Eine frühe Schrift Joachims von Fiore. Hannover: Hahnsche Buchhandlung.

Klemm, E., 1980. Die romanischen Handschriften der Bayerischen Staatsbibliothek 1. Die Bistümer Regensburg, Passau und Salzburg. Wiesbaden: Reichert.

Klemm, E., 1998. Die illuminierten Handschriften des 13. Jahrhunderts deutscher Herkunft in der Bayerischen Staatsbibliothek [ = Katalog der illuminierten Handschriften der Bayerischen Staatsbibliothek in München 4]. Wiesbaden: Reichert.

Knaus, H. 1979. Die Handschriften der Hessischen Landes- und Hochschulbibliothek Darmstadt. Bd. 4: Ältere theologische Texte. Wiesbaden: Harrassowitz.

Lauer, P., 1940. Catalogue général des manuscrits latins. Tome II (Nos. 1439-2692). Paris: Bibliothèque nationale de France.

Laureys, M., 1992. 'Johannes de Meerhout and his annotations to the Odes and Epodes of Horace'. In: W. Verbeke, M. Haverals (eds.), Serta Devota in Memoriam Guillelmi Lourdaux. Pars Prior. Devotio Windeshemensis. Leuven: Leuven University Press, 383-413.

Markus, R. A., 1957. 'St. Augustine on Signs'. Phronesis 2, 60-83.

Oury, G.-M., 1971. 'Hervé de Bourg-Dieu'. In: Dictionnaire de Spiritualité. Paris: Beauchesne, 373-377.

Paris, G., 1865. De Pseudo-Turpino. Paris: A. Franck.

Parlett, D. S., 1986. Selections from the Carmina Burana. A Verse Translation. Harmondsworth: Penguin.

Patera, A., Podlaha, A., 1910. Soupis rukopisů Knihovny Metropolitní kapitoly pražské. První část: A-E [Catalogue of manuscripts of the Library of Metropolitan Chapter in Prague. First volume: A-E]. Praha: Česká Akademie.

Pedretti, M., 2011. 'Letture politiche delle opere catalane di Anselm Turmeda'. Studi Ispanici 36, 11-50.

Petrucci, A. 1970. 'Censimento dei codici dei secoli X-XII, Roma, Biblioteca Vallicelliana'. Studi medievali $11,1058-1060$. 
$P L=$ Patrologiae cursus completus [...] Series Latina. 1-221. Paris: J.-P. Migne, 1844-1865.

Professione, A., 1967. Inventario dei manoscritti della Biblioteca capitolare di Ivrea. Alba: Tip Domenicane.

Quicherat, J., 1879. Catalogue général des manuscrits des bibliothèques publiques des départements. Tome V. Paris: Imprimerie nationale.

Raabe, W. K., 1969. Der heilige Born. Ein Geheimnis. Auf dunklem Grunde. Die schwarze Galeere. Göttingen: Vandenhoeck \& Ruprecht.

Robert, U., 1891. Histoire du pape Calixte II. Paris: Alphonse Picard.

Schmidt, P. G., 2008. 'La lingua del diavolo'. Filologia mediolatina 15, 69-74.

Schwarzmaier, H., 1962. 'Mittelalterliche Handschriften des Klosters Ottobeuren'. Studien und Mitteilungen zur Geschichte des Benediktiner-Ordens und seiner Zweige 73/2-4, 7-23.

Smalley, B., 1982. The Study of the Bible in the Middle Ages. 3rd corrected edition. Notre Dame: Notre Dame University Press.

Southern, R., 1972. 'Aspects of the European Tradition of Historical Writing 3. History as Prophecy'. Transactions of the Royal Historical Society: fifth series 22, 159-180.

Stegmüller, $R B=$ F. Stegmüller, Repertorium Biblicum Medii Aevi. http://repbib.uni-trier.de/cgi-bin/rebihome.tcl [accessed July 23, 2020].

van den Gheyn, J., 1902. Catalogue des manuscrits de la Bibliothèque royale de Belgique. Tome deuxième. Patrologie. Bruxelles: Henri Lamertin.

van den Gheyn, J., 1905. Catalogue des manuscrits de la Bibliothèque royale de Belgique. Tome cinquième. Histoire - Hagiographie. Bruxelles: Henri Lamertin.

Vernet, A., 1948. 'Notice et extraits d'un manuscrit d'Edimbourg (Adv. 18.6.12, 18.7.8, 18.7.7)'. Bibliothèque de l'école des Chartes 107, 33-51.

Vernet, A., 1950. [Rev.] 'Curtius (Ernst Robert), Europäische Literatur und lateinisches Mittelalter'. Bibliothèque d'humanisme et renaissance 12, 377-387.

Vernet, A., 1981. Études médiévales. Paris: Études augustiniennes.

Walther, H., 1959. Initia carminum ac versuum Medii Aevi posterioris Latinorum. Göttingen: Vandenhoeck \& Ruprecht.

Wannenmacher, J. E., 2005. Hermeneutik der Heilsgeschichte. De septem sigillis und die sieben siegel im Werk Joachims von Fiore. Leiden: Brill.

Werner, J., 1905. Beiträge zur Kunde der lateinischen Literatur des Mittelalters aus Handschriften gesammelt. Aarau: H. R. Sauerländer.

Westra, H. J., Kupke, T., 1998. The Berlin Commentary on Martianus Capella's De nuptiis Philologiae et Mercurii. Book II. Ed. by H. J. Westra and T. Kupke [= Mittellateinische Studien und Texte 23]. Leiden: Brill.

Wind, P., 1982. 'Die lateinischen Handschriften von St. Peter'. In: Ausstellungskatalog: St. Peter in Salzburg. Schätze europäischer Kunst und Kultur. Salzburg: Amt der Salzburger Landesregierung, Kulturabt., $187-192$.

Wodek, Z., Zathey, J., Zwircan, M., 1980. Catalogus codicum manuscriptorum medii aevi latinorum qui in Bibliotheca Jagellonica Cracoviae asservantur. Volumen I numeros continens inde ab 8 usque ad 331. Wrocław: Inst. Ossolinianum Officina.

Young, J., Aitken, P. H., 1908. A Catalogue of the Manuscripts in the Library of the Hunterian Museum in the University of Glasgow. Glasgow: J. Maclehose and sons.

Ziegler, Ch., Rössl, J. 1985. Zisterzienserstift Zwettl. Katalog der Handschriften des Mittelalters. Teil I. Codex 1-100. Wien: Anton Schroll.

Ziegler, Ch., Rössl, J., 1997. Zisterzienserstift Zwettl. Katalog der Handschriften des Mittelalters. Teil IV. Codex 301-424. Zwettl: Scriptorium ordinis Cisterciensium.

Ziolkowski, J., 1996. 'Theories of Obscurity in the Latin Tradition'. Mediaevalia 19, 101-167. 


\title{
STRASTI A SLASTI INTERPRETACE A APROPRIACE OBSKURITY. VERSUS MALIGNI ANGELIVE 12.-15. STOLETÍ
}

Studie se zabývá středověkými metodami interpretace a charakterem rukopisné tradice na př́kladu krátké obskurní básně, která je v některých rukopisech nazvaná Versus maligni angeli. Přestože její původ není znám a její obsah je velmi nejasný, dočkala se čtyř různých komentářů. Každý z komentátorů vysvětluje, že báseň je křestanská, jednotliví vykladači se ale liší v detailech interpretace. Každý také jiným způsobem obhajuje fakt, že je báseň připisovaná dáblu. Při interpretaci tohoto velmi neobvyklého pramene všichni používají tradičních metod biblické exegeze. Přestože jde pouze o drobné dílko, tento př́pad poukazuje na středověkou interpretační flexibilitu, stejně jako hlubokou zvědavost a touhu po poznání stvořeného světa. $\mathrm{V}$ prríloze je zahrnut seznam rukopisů a edice dvou glosovaných verzí této básně.

\author{
Lucie Doležalová \\ Charles University, Prague \\ lucie.dolezalova@ff.cuni.cz
}




\section{Appendix I: \\ The list of the manuscripts of the Versus maligni angeli}

The manuscripts are listed in an alphabetical order according to the cities where they are currently kept. The descriptions are very brief and should serve for a basic orientation. They inform about the version of the verses that is included in the manuscript, the folios where they appear in the manuscript, its dating, provenance (sometimes later ownership is added in the brackets) and reference to catalogue entry (if detailed catalogue is available) or other relevant literature. Manuscript witnesses of peculiar versions of the Versus (refered to in the study) are transcribed here in full. This is meant as a mere shortlist.

Basel, Universitätsbibliothek, A. II. 25

verses + "apologetic" commentary (attr. to Joachim of Fiore) as: expositio versuum extraneorum, ff. 43r-45v

XV (ca. 1430-1445)

Basel (owned by Carthusians in Basel)

Besançon, Bibliothèque municipale, 862

verses + interlinear glosses, f. 24r

XII

?, owned by Nicolas Hocquigny and C. R. Jardel (b. ca. 1720)

Jeudy, Riou (1989: 758)

Bourges, Bibliothèque municipale, 105

verses (+ image of the winds), f. $95 \mathrm{v}$

XI-XII

Chezal-Benoît?

Bruxelles, Bibliothèque royale de Belgique, 10038-53 (978)

verses + "apologetic" commentary; as: Versus quos spiritus nequam composuit, ff. 49v-54v XIII

? (later in Bibliothèque nationale de France)

van den Gheyn (1902: 50-52)

Bruxelles, Bibliothèque royale de Belgique, 5387-96 (3168)

verses + "apologetic" commentary, ff. 116r-119v

early XIII (or late XII)

Gembloux monastery

van den Gheyn (1905: 122-124)

Charleville-Mézières, Bibliothèque municipale, 117

verses + "exegetical" commentary, ff. 1v-19r

XII

Signy abbey? (Cistercian; later there)

Quicherat (1879: 602-603) 
Darmstadt, Hessische Landes- und Hochschulbibliothek, 947

verses + "novelistic" commentary, 105r-107r

XII-XIV, verses XIV

Niederrhein or Netherlands (in the 15th c. in Carthusian monastery of St. Barbara in Köln)

Knaus (1979: 220-222)

Edinburgh, National Library of Scotland, 18.6.12

verses, ff. $34 \mathrm{v}-35 \mathrm{r}$

XII-XIII

Thorney (Benedictine, there till 1539)

Vernet (1981: 177-195)

\section{Freiburg im Breisgau, Universitätsbibliothek, 9}

verses + "moral" commentary (as interlinear), f. 53v

2/2 XII

Ottobeuren (Benedictine)

Hagenmaier (1974: 12-14), Schwarzmaier (1962: 18, no. 21)

Glasgow, University Library, Hunterian Museum 205 (U.1.9)

verses, f. IIIr

XII, XIV, verses an addition from XVI

?

Young, Aitken (1908: 147-148)

Heiligenkreuz, Stiftsbibliothek, 11

"moral" commentary, ff. 150r-150v

XII

? (owned by the Cistercian abbey in Heiligenkreuz)

the manuscript is digitized and available through https://manuscripta.at/diglit (accessed July 3, 2020)

Innsbruck, Universitäts- und Landesbibliothek Tirol, 355

verses + fragment of appropriated "apologetic" commentary, ff. 82r-82v

XIV (1334)

Tirol; scribe Cornutus (expl.: Anno Domini 1334 in die beate Lucie virginis, conpletus est auctor iste nomine Cornutus per manus Rudolff Scolaris in Tyrol)

Ivrea, Biblioteca capitolare, VI (74)

verses + "apologetic" commentary (linked to Joachim de Fiore), ff. 64r-68v

XIV or XIV-XV

probably from Ivrea

Professione (1967: 90-92) 
Karlsruhe, Badische Landesbibliothek, St. Peter Perg. 12

verses + with interlinear glosses, f. 120v

XII, additions XIII-XIV

St. Peter im Schwarzwald [?] (Benedictine), bound at the beg. XV, prob. in Konstanz

Heinzer, Stamm (1984: 30-31), Heinzer (1988: 331-346).

\section{Kraków, Biblioteka Jagiellońska, 126}

verses + "novelistic" commentary, f. $45 \mathrm{r}$

XV (ca. 1440) and XVI

linked to the council of Basel, to Italian humanists, to Poland-owned by Johannes de Ludzisko (d. before 1460), then by Petrus Gaszowiec (d. 1474)

Wodek, Zathey, Zwircan (1980: 99-115)

\section{Laon, Bibliothèque municipale, 23}

verses + interlinear glosses, as: Versus diaboli, f. $114 \mathrm{v}$

XII

from Vauclair (Cistercian)

Guglielmetti (2002: 300 and lxxxvi-lxxxviii)

\section{Madrid, Biblioteca Nacional, 9731 (olim Ee 47)}

verses + "apologetic" commentary (linked to Joachim de Fiore) as: Expositio versuum extraneorum, ff. $182 \mathrm{v}-184 \mathrm{v}$

XIV

from Southern France or Italy (belonged to papal library in Avignon, features in catalogue from 1369)

Jostmann (2006: 391-396), Wannenmacher (2005: 269-276)

\section{Merseburg, Domstiftsbibliothek, 40}

different verses:

(f. 188v:) Achmata thonti post oxica loxica lyri euenit yarras olypolyri que lyvarras edypol edulpes malagraphanus ulpes hoc caput erontis latet hoc in vertice montis.

(f. 194r:) Contra omnes febres preter mortales scribe in plumbo in nomine $p$ et $f$ et ss hec tibi proficiant. sed prius nouem dies comburet totum.

Achmara toucha tyri post toxica noxica leri

euoluit scarras olavii levyque lymarras

edepol adulpes malagraphanus alphanus wlpes

hoc caput edrontis latet hoc inuertice montis

cantat gallina fugam cape pandido lyna

sed nota quod sin canones musicata vocabula et karacteres non debent scribi et poni

XIV (1388 [dated on 188v])

Petrus Sparnow (prior of Merseburg)? 
Montpellier, Bibliothèque Universitaire, Méd. H.4

verses + "apologetic" commentary, ff. 127r-128v

XII-XIII

Troyes, Oratoire (+ Pithou)

Castets (1887)

München, Bayerische Staatsbibliothek, clm. 2561

verses + "moral" commentary, no title, ff. $161 \mathrm{v}-162 \mathrm{v}$

$1 / 4$ XIII

Aldersbach (Cistercian)

Klemm (1980: 152-153, plates 588, 589)

München, Bayerische Staatsbibliothek, clm. 2611

verses, different, f. 123v:

si mihi rhetorica vis tota phylosophy illuminare [? looks like ihlm[um]]

ammaratonta tyri post doxia noxia nili

elipolis carras poli polilique lauarras

edupes et ulpes mala graphanas alpanus ulpes

trox caput erontis iacet hoc in uertice montis

obpositum montem conscendere cer [nis o-hole in $\mathrm{ms}$.] rontem

arma tua dextra capiens effer caput extra

si proclamat clamor eius Deo caritati inter et exterius sit perunctus

[the preceding and following notes do not seem to be linked]

XIII (1225-1250)

Aldersbach (Cistercian, surely there in 14th and 15th c.)

Cat.: Klemm (1998: 99, plates 237 and 239)

München, Bayerische Staatsbibliothek, clm. 18921

verses + much shortened "moral" commentary, f. $22 \mathrm{v}$

+ a reference to another (now lost) manuscript which contained a full version of the commentary (Nota quod istos versus et exposicionem plenius invenies in passionali parte estivali post legendam de translatione beate Marie Magdalene, f. 22v)

XIV

Tegernsee (Benedictine)

München, Bayerische Staatsbibliothek, clm. 23390

fragment of the "novelistic" commentary but a different version, f. 56r

XIII

Kaisheim (Cistercian)

Klemm (1998: 151)

New York, Pierpont Morgan Library, M. 765

only the first verse: Oppositum montem conscendere cernis orontem, f. 148v

end X, the verses XI, explicit added XII

Amorbach (Benedictine, Würzburg, Germany) 
Oxford, Bodleian Library, Digby 53

verses, different, f. 44r, as: Versus demonis Johanni heremite quibus occupatus solvendis cessaret ab oracione:

admaratonta tyri post toxica noxica liri

eliuaris carras pololique polorique riuarras

edipus edulpes malagrafanas alfanus ulpes

trans capud orontis iacet hoc in uertice montis

XII (end)

Bridlington, Yorkshire, Augustinian Priory of St. Mary the Virgin

Hoffmann (2004: 14-15)

Paris, Bibliothèque nationale de France, lat. 1628

verses + interlinear glosses, f. 145r

XII

St. Amand-en-Pévèle (shelfmark E 109 on f. 1, 2r up: Liber bibliothecae Sancti Amandi in Pabula)

Lauer (1940: 98)

Paris, Bibliothèque nationale de France, lat. 2877A

verses, f. $27 \mathrm{v}$

XII

Saint-Martial de Limoges (Benedictine)

Paris, Bibliothèque nationale de France, nouvelles acquisitions lat. 1543

verses + interlinear glosses, f. 125v

$2 / 2$ XII

Hautmont[?] (Benedictine)

[Peñiscola Castle, no. 134 = Santa Fe (Cistercian monastery by Saragossa)]

CATALOGUE ENTRY ONLY

verses + "apologetic" commentary (Joachim)

XIV (1348?)

? (library of the Popes of Avignon)

(omitted from the tables since it might be identical with the surviving Madrid ms.)

Faucon (1887: 51, no. 134)

[Pontigny 204 LOST]

CATALOGUE ENTRY ONLY

verses [+ "apologetic" commentary?]

XII

Pontigny (Cistercian) 
Praha, Archiv Pražského hradu, fond Knihovna metropolitní kapituly Sv. Víta, A 79/4 (no. 151)

verses + "novelistic" commentary; as: exposicio versuum daemonis cuiusdam, ff. 286r-287r $\mathrm{XV}(1410$ 's)

?

Patera, Podlaha (1910: 102-103)

Praha, Archiv Pražského hradu, fond Knihovna metropolitní kapituly Sv. Víta, B 62 (no. 371)

verses + glosses + "novelistic" commentary, f. 136v

XIV

?

Patera, Podlaha (1910: 219)

Roma, Biblioteca Vallicelliana, E 5

verses + "apologetic" commentary, ff. 276v-278r

XII-XIII

Fleury, St. Benoît sur Loire (Benedictine), later belonged to Achiles Stazius

Petrucci (1970: 1058-1060)

Salzburg, Stiftsbibliothek St. Peter, A.VII.17

verses + "novelistic" commentary, ff. $85 \mathrm{r}-85 \mathrm{v}$

end XII-beg. XIII

St. Peter in Salzburg (Benedictine)

Wind (1982: 190)

Schaffhausen, Ministerialbibliothek, Min. 42

only the first verse: Oppositum montem conscendere cernis orontem, f. $151 \mathrm{v}$

$2 / 4$ IX, the verse is an addition from XII

Mainz, later Schaffhausen (cat. 1589)

Gamper, Knoch-Mund, Stähli (1994: 134-135)

Tours, Bibliothèque municipale, 257 (olim 457)

verses + "apologetic" commentary; as: Versus contra hereticos ad ecclesiam, ff. 134v-136v 2/2 XII

Saint Gatien cathedral, Tours

the verses following Herveus' com. to the Cena Cypriani

Collon (1900: 189)

Uppsala, Universitetsbibliotek, C 228

only 5 verses, different, badly readable, f. $302 \mathrm{v}$

Amara tanta tiri post thosica losica liri

Eliuolas farras poli polique nauarras

ydipus edipes mala cesanus affanus wlpes 
trans capud horrentis iacet hic sub uertice montis

Fya lenera scharri polmi polirrique liwarri

XIII-XIV (1300)

Paris University?, Dominican context

Andersson-Schmitt, Hedlund (1988: 101-107)

Uppsala, Universitetsbibliotek, C 377

only 6 verses, different, f. 2 r:

Amara tonta tyri post hos sycalos sykaliri

Ely voly skarras warras poly lyque lyuarras

Transcaput errontis iacet hoc in vertice montis

ut puriel abyel baldala gut et[?] guttam

luon[???] pius pater est paux filius spiritus sanctus

kyes kyebis alus aluster alus

XIV

unknown, Sweden?

Andersson-Schmitt, Hallberg and Hedlund (1991: 476-485)

Vatican, Biblioteca Apostolica Vaticana, Ottobonianus lat. 1758

verses + a fragment of appropriated "apologetic" commentary, ff. 158v-159r

XV

Rome?, old shelfmark 296

Wien, Österreichische Nationalbibliothek, Pal. lat. 303 [Novus 392]

verses (different, fragmentary: dudum tibi seruit. Iam perlatura constat tibi. iacet hoc in vertice montis. circumstabunt acies et vociferabunt. codoxia noxia nili. eris hoc in limine),

f. $64 \mathrm{r}$

XIV

?

Wien, Österreichische Nationalbiblothek Pal. lat. 1062

verses + "novelistic" commentary, ff. 89v-90r

XV

Hungary?

Wien, Österreichische Nationalbibliothek, Pal. lat. 2521 [Philol. 413]

verses, ff. 33v-34r

XII

?

Wien, Österreichische Nationalbibliothek, Series nova 12702

verses with glosses, f. 80r

XV (1444) 
Korsendonk (priory in Belgium), written by Johannes de Meerhout (= Jan van Meerhout van Diest, d. 1476)

Laureys (1992: 383-387)

Wooster, Library of the College of Wooster (Special Collections), Ohio (no call no.) verses + "apologetic" commentary, ff. 117v-120r

$\mathrm{XV}$

Italy, Genova?

the verses following Herveus' commentary to the Cena Cypriani

de Ricci (1937: 1978)

Wrocław, Ossolineum, 601

verses + "novelistic" commentary, ff. 325r-326v

$\mathrm{XV}$

Cracow (f. 600v: sunt finite per Iacobus de Cossow in vigilia sancte Zophie Cracovie in bursa Ierusalemitana, reportate anno Domini 1469)

\section{Zwettl, Stiftsbibliothek, 13}

"moral" commentary (verses integrated), f. 207v

XIII $(1 / 4)$

Zwettl (Cistercian); scribe Chunradus

Ziegler, Rössl (1985: 31-37)

Zwettl, Stiftsbibliothek, 355

verses + "novelistic" commentary, f. 105v

late XII (4/4)

Zwettl (Cistercian)

Ziegler, Rössl (1997: 186-189) 


\section{Appendix II: \\ Two glossed versions of the Versus maligni angeli}

\section{Paris, BnF, n. a. lat. 1543, f. $125 v$}

concupiscentis seculi; montem Christum; triumphare de principe mundi; significantem tenebras i.e. mundum

Oppositum montem conscendere cernis orontem

lucis; quo nesciat sinistrum pugnando contra vicia spiritaliter; id est mentem carnem Arma tua dextra capies effer caput extra

Hinc gladio multos umbris mactabis inultos

et propter hoc ecclesia; vocem predicationis; retia fidei per predicationem Hinc et gallina dat vocem pandite lina

quoniam hoc intelligas; unitas predicatorum; intelligentie Sed prius hoc unus puerorum fert tibi munus

vetus lex; carnalibus preceptis; nunc servit filius gratie; servivit filius agar Lanx que cum carne tibi dudum servit agarne

id est incarnato Christo; de lege spiritaliter intelligenda Iam prolatura tibi constat munera plura

scripturarum

confirmatione sanctos predicatores; hereticos videte ad verbum evangelii minutos Panibus indutos indutos piscesque videte minutos

id est diabolus; caput malorum; prosternitur id est in presenti ecclesia que corpus est Christi Trax caput orontis iacet hoc in corpore montis

diabolum; malorum; cum eo dampnato plangentes semetipsos malorum Quę circumstabant acies et vociferabant

In secundo adventu d[omini] uana gloria fuit mundi

Amaratunta tibi codoxia noxia nili

et suspense spiritales penitens si sicut vixeris in munere huius vite non adtenderas sint tibi; lugens; ad amorem seculi

Pensa tibi dippus eris hoc in munere lippus

celes[tis] desiderii sapientia damnat in plateis; sapientia

Victus amore pio sic cantat maxima clyo

Ave Maria 


\section{Paris, BnF, lat. 1628, f. 145r}

This version was transcribed also by Baehrens (1916: 43), who, however, restituted classical Latin spellings in his presentation of the text. A special feature of this copy are musical notes.

concupiscentiis seculi; triumphare de principe mundi; tenebras significantem mundum Christum Oppositum montem conscendere cernis orontem

lucis que nesciat sinistra; id est mentem; carnem pugnando contra vicia Arma tua dextra capiens effer caput extra

propter hoc; ecclesia; predicationis; id est recia fidei per predicationem

Hinc et gallina dat vocem pandite lina

quam hoc intelligas; unitas predicatorum; intelligentie

Sed prius hoc unus puerorum dat tibi munus

vetus lex; carnalibus preceptis; filius agar nunc servit filiis gratie

Laus que cum carne dudum servivit agarne

id est incarnato Christo; de lege spiritaliter intelligenda

Iam prolatura constat tibi munera plura

scripturarum sanctos predicatores; hereticos; ad verbum evangelii

Panibus indutos piscesque videte minutos

diabolus, corpus malorum, proponitur in presenti ecclesia que est corpus Christi

Trux caput orontis, iacet hoc in corpore montis

id est diabolum; malorum; plangentes semetipsos

Quem circumstabant acies et vociferabant

in secundo adventu Christi; vana gloria; mundi

Amaratonta tili cenodexia noxia nili

impense spiritales sint tibi; lugens si sic in itinere huius vite vixeris

Pensa tibi edippus eris hoc in limine lippus

celestis desiderii; sapientia clamat in plateis; sapientia

Victus amore pio sic cantat maxima clyo 